\title{
Status of historical seismology in Japan
}

\author{
Katsuhiko Ishibashi \\ Department of Earth and Planetary Sciences at Faculty of Science, Kobe University, Kobe, Japan
}

\begin{abstract}
Japan's combination of high seismicity and a long history has produced copious written records of historical earthquakes. Systematic collection and investigation of such historical documents began late in the 19th century. Now, almost all of Japan's known historical materials on earthquakes have been transcribed into 25 printed volumes. The collections include records of about 400 destructive earthquakes from A.D. 599 to 1872. Epicentral coordinates and magnitudes have been estimated for about half these events and details of earthquake and tsunami disasters have been summarized in catalogues. The space-time pattern of great Tokai and Nankai earthquakes is a good example of revealed earthquake history. The existing collections of historical sources, however, contain low-quality records that produce errors and fictitious (fake) earthquakes, and are difficult of full utilization because of volumes. Moreover, there are peculiar problems to Japan's historical times such as calendar and time of day. Systematic ways of estimating seismic intensities, epicenters, focal depths and magnitudes have not yet been established. Therefore, historical earthquake catalogues are yet incomplete. Constructing a reliable database of the whole historical documents in collaboration with historians to give wide-ranging researchers easy and full utilization of old earthquake records is urgent task. Revision of earthquake catalogues and construction of a seismic intensity database with international standard are also necessary.
\end{abstract}

Key words historical seismology - Japan - historical documents - earthquake catalogue - database

\section{Introduction}

The seismic activity in and around Japan is very high because it is located in an active plate boundary zone where four lithospheric plates converge on one another. The Japanese people have suffered from severe earthquake and tsunami disasters frequently throughout their history, and have left a huge amount of written documents on these events. Based on them, study of historical earthquakes has

Mailing address: Prof. Katsuhiko Ishibashi, Department of Earth and Planetary Sciences at Faculty of Science, Kobe University, Kobe, 657-8501 Japan; e-mail: ishi@kobe-u.ac.jp been intensively conducted in Japan for more than a century.

Purposes or contents of historical earthquake study can be categorized into three. The first is scientific observation and analysis of historical earthquakes such as underground natural phenomena, that is, historical seismology, an indispensable branch of earthquake science. The second is investigation of historical earthquake disasters including physical and mental aspects from the viewpoint of present and future earthquake countermeasures (e.g., Miki, 1979). The third is analysis of historical societies and people related to earthquake disasters from the viewpoint of social and human sciences (e.g., Kitahara, 1983). Though these three fields are interdisciplinarily related to one another and should collaborate closely, this paper focuses on the first field and describes the past progress, present situation and future problem of historical seismology in Japan. 
Both rekishi-jishin (historical earthquakes) and ko-jishin (old earthquakes, paleo-earthquakes) are used in Japan to denote earthquakes in historical times. Concerning these terms, Ishibashi (1987) proposed definitions as follows; «paleo-earthquakes» is the general term for earthquakes during the pre-instrumental period («pre-instrumental earthquakes») including «historical earthquakes» and «prehistoric earthquakes», whereas «historical earthquakes» means earthquakes in pre-instrumental historical times when written records exist, and «prehistoric earthquakes», ones during older times without written records including the Holocene and Pleistocene. We should note, however, that pre-WWSSN (World-Wide Standardized Seismograph Network) (pre-1963) earthquake records and earthquakes are sometimes called as «historical seismograms and earthquakes» (e.g., Lee et al., 1988).

The time window of historical earthquakes as defined above differs from place to place in the world. In Japan, the beginning of the age of historical earthquakes is about the 6th century. The oldest known earthquake dates back to A.D. 599, which is recorded in Nihon Shoki (e.g., Kuroita, 1951, 1952), the Japan's oldest chronicle completed in 720. Although an older earthquake is also described in Nihon Shoki and it is often said of A.D. 416 (e.g., Usami, 2002b, 2003), historical events before the early 6th century A.D. belong to a mythical age for which precise dating is almost impossible; the year of 416 is a holdover of the ultranationalistic view of history during the pre-World War II period claiming that Japan had been founded by Emperor Jin'mu in 660 B.C., which had a strong influence on the pre-1945 historical seismology as well.

The lower limit of the age of historical earthquakes in Japan is usually considered to be 1872 or 1884 . The year 1872 is taken because the Gregorian solar calendar was adopted and instrumental observation of earthquakes, though very primitive, was started in Japan in 1873 (e.g., Usami, 1979, 1982, 1988). The year 1884 is taken because Utsu's $(1979,1982,1988)$ parametric catalogue of large earthquakes $(M \geq 6)$ and damaging earthquakes $(M<6)$ in Japan based on careful re-interpretation of instrumental data be- gins from 1885. The method of historical seismology, however, is useful even after these years, especially until the 1923 great Kanto earthquake $\left(M_{w} 7.9\right)$ or until around the end of World War II. Takemura (1999, 2001), for example, investigated strong ground motions due to the 1923 Kanto earthquake and very large aftershocks immediately afterwards based mainly on many descriptions of personal experiences.

Archaeoseismology and paleoseismology have recently begun to complement historical earthquake research in Japan (e.g., Sangawa, 1992; Ota and Shimazaki, 1995; Matsuda, 1999). Field records of historical earthquakes include surface fault displacements, surface fractures, landslides, liquefaction features, uplifted marine terraces, subsided marshes, damaged archaeological sites, tsunami deposits, turbidites, dendrochronological materials, and remnant magnetization. For many unknown earthquakes during historical times, whose written records do not exist, archaeoseismology and paleoseismology are the only ways to investigate. In this review, however, I will concentrate on historical seismology dealing with written historical records of old earthquakes.

Japan is a volcanic country as well, having experienced violent volcanic eruptions many times, and study of historical eruptions has been conducted in parallel with that of historical earthquakes. Therefore, what will be discussed in this paper can be applied to historical volcanology to a considerable extent. As for the investigation of historical natural disasters other than earthquakes, tsunamis and volcanic eruptions, collaboration with historical seismology has not been active in Japan so far.

\section{Tectonic setting and seismicity of Japan}

The Japanese Islands are located in the midst of the plate convergence zone at the northwestern margin of the Pacific Ocean where two oceanic plates are being subducted beneath two continental plates (fig. 1). Northeast Japan is considered to be on the North American plate or the Okhotsk (Sea of Okhotsk) microplate, and southwest Japan, on the Eurasian plate or the Amurian microplate. Al- 


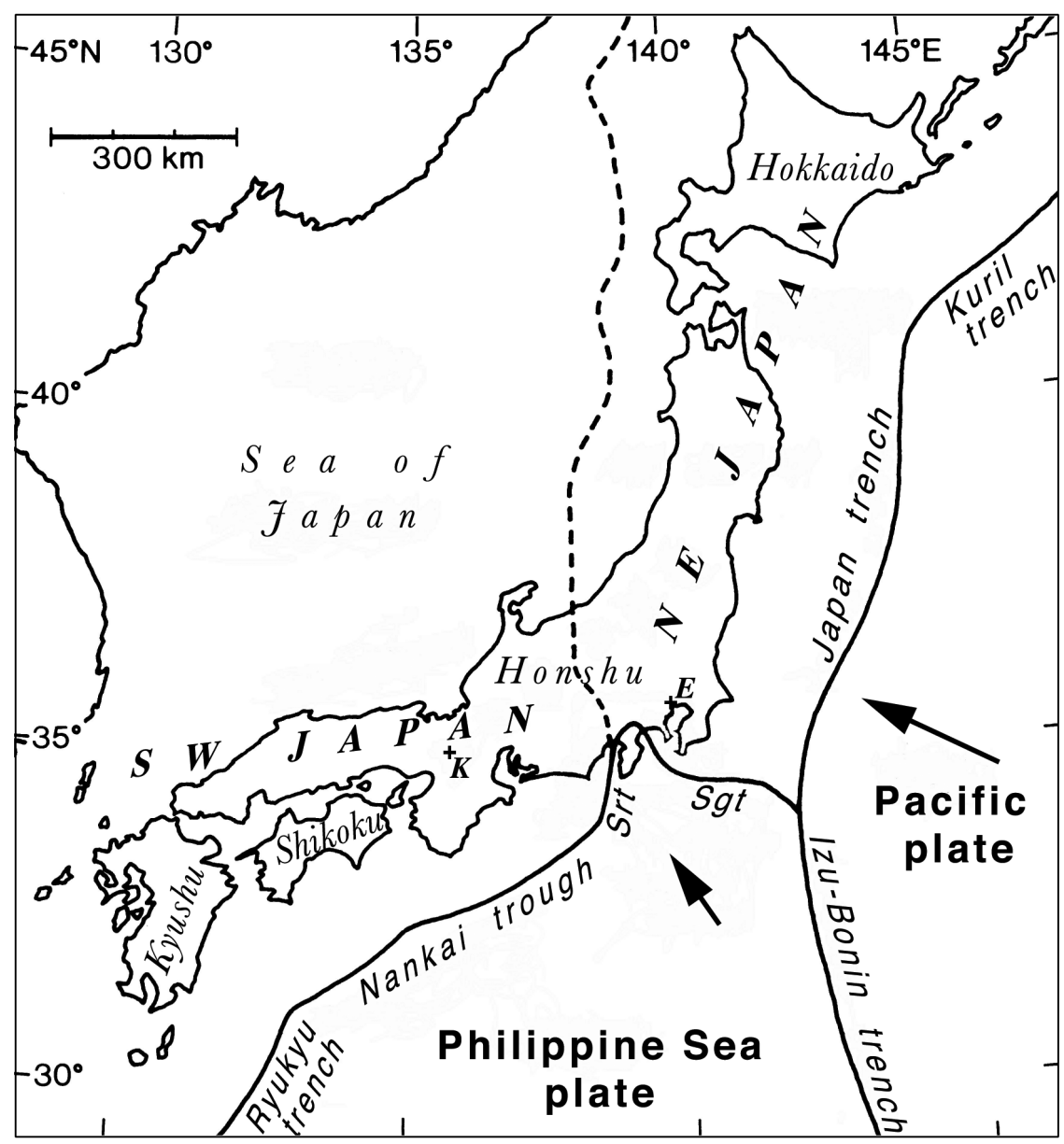

Fig. 1. Plate-tectonic setting of the Japanese Islands. Hokkaido, Honshu, Shikoku and Kyushu are four main islands of Japan. Arrows indicate the motions of the Pacific and the Philippine Sea plates relative to northeast Japan roughly. Subduction boundaries of these two plates are shown by solid lines. Sgt - Sagami trough; Srt - Suruga trough. As for the continental plates and the boundary between them (broken line), see text. $\boldsymbol{K}$ and $\boldsymbol{E}$ denote two old capitals, Kyoto and Edo (now Tokyo), respectively.

though the plate geometry and kinematics of these two blocks remain controversial, there is general agreement that these two parts of Japan have been converging with each other in an east-west direction at the rate of 1 to $2 \mathrm{~cm} / \mathrm{yr}$, roughly, since the late Pliocene or the early Pleistocene, and that the juvenile convergence boundary between the two plates runs along the west coast of northeast Japan and crosses the middle of Honshu toward the Suruga trough.
The Philippine Sea plate is being subducted beneath the southern part of northeast Japan (Tokyo metropolitan area and its vicinities) and beneath southwest Japan. The convergence directions and rates are north-northwestward and about $3 \mathrm{~cm} / \mathrm{yr}$ at the Sagami trough, and westnorthwestward and 4 to $6 \mathrm{~cm} / \mathrm{yr}$ at the SurugaNankai trough and the Ryukyu trench. The Pacific plate is being subducted beneath northeast Japan west-northwestward at the Kuril and 
Japan trenches at the rate of about $8 \mathrm{~cm} / \mathrm{yr}$ and beneath the Philippine Sea plate west-northwestward at the Izu-Bonin trench at the rate of about $6 \mathrm{~cm} / \mathrm{yr}$.

Because of these plate interactions the seismic activity in and around Japan is very high (fig. 2). Figure 2 shows only the shallow seismicity, but deep seismic zones reach as deep as about $600 \mathrm{~km}$ in the subducted Pacific plate and as deep as about $300 \mathrm{~km}$ in the subducted Philippine Sea plate along the Ryukyu trench. All the four types of large or great earthquakes in terms of plate tectonics in subduction zones take place in Japan (fig. 3). They are interplate events along the subduction boundaries, shallow intraplate events in the crust of overriding plates, offshore shallow intraplate events in the oceanic plates, and deeper slab earthquakes in slabs (subducted oceanic plates). Major historical disastrous earthquakes in Japan include great interplate events along the Kuril and Japan trenches, Sagami trough and Suruga-Nankai trough, presumably interplate events

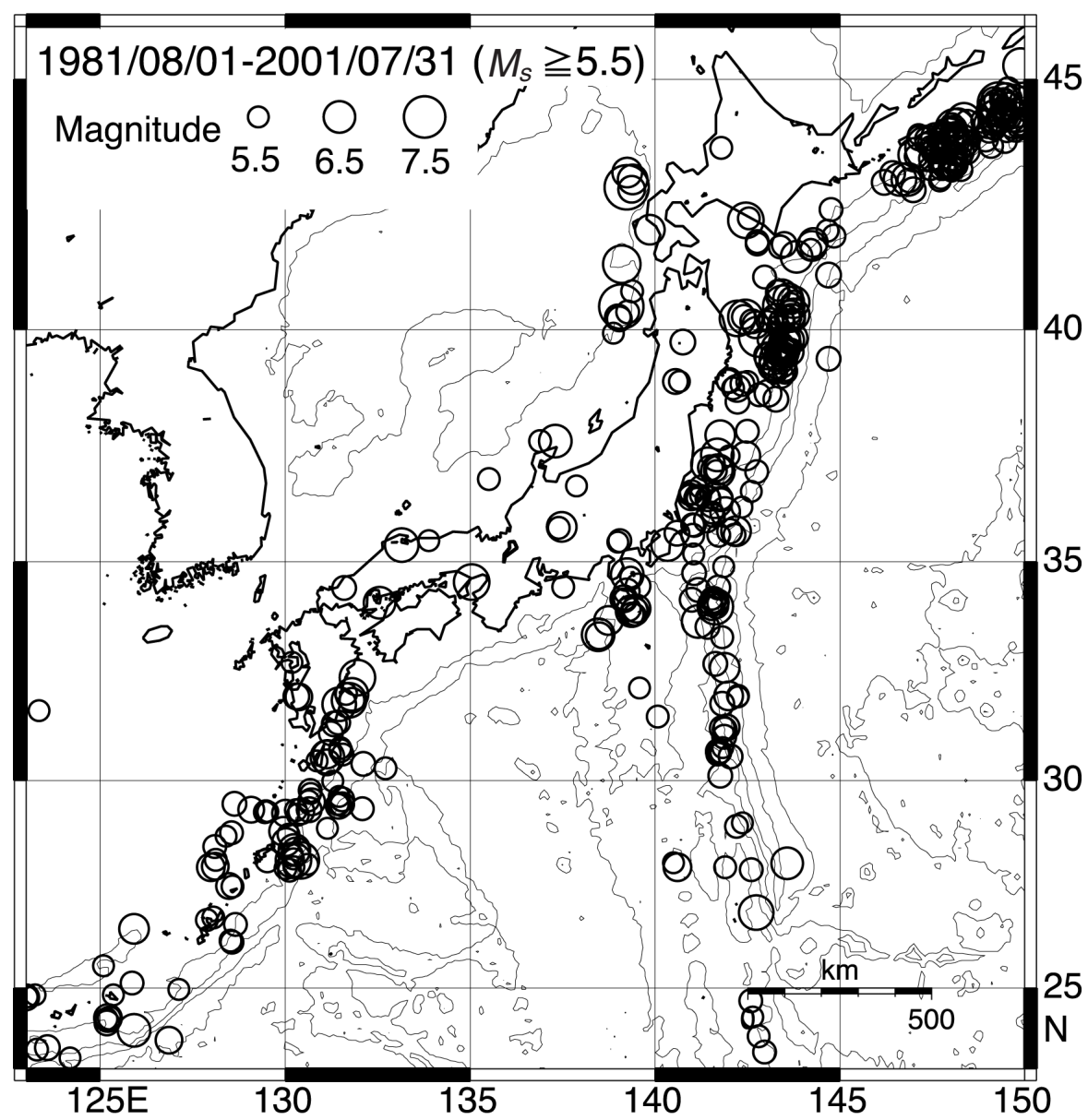

Fig. 2. Epicentral distribution of earthquakes of $M_{S} 5.5$ or larger and with hypocentral depths less than $60 \mathrm{~km}$ in and around Japan during the period from 1 August 1981 to 31 July 2001 after the International Seismological Center. Interval of isobaths is $2000 \mathrm{~m}$. 


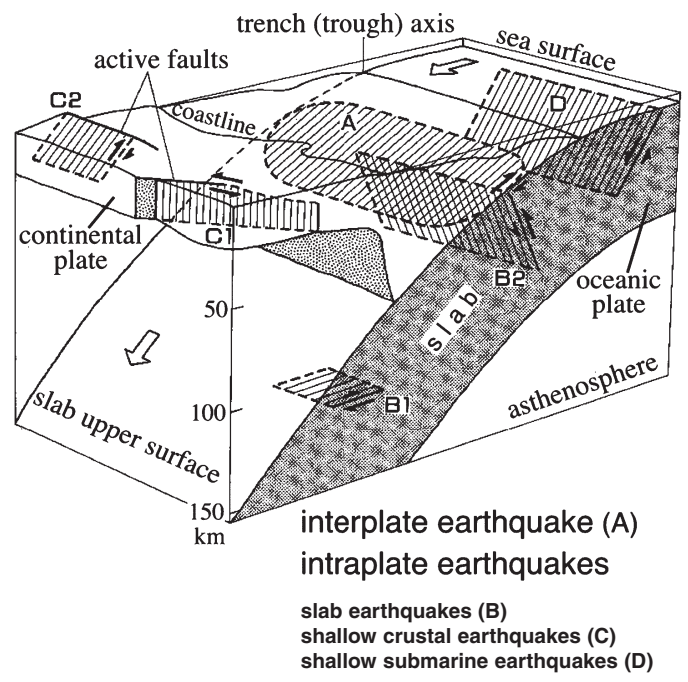

Fig. 3. Schematic illustration of fault planes of four types of large or great earthquakes in terms of plate tectonics around Japan.

along the west coast of northeast Japan, large or great shallow inland events, great intra-oceanicplate events far-east-off northeast Japan, and large or great slab events within the subducted Pacific and Philippine Sea plates. The broad seismicity gap along the Suruga-Nankai trough delineated in fig. 2 is the place where great interplate earthquakes have recurred in the past and are anticipated to occur in the near future as explained in Section 7.1.

At present, the Japan Meteorological Agency (JMA; called the Central Meteorological Observatory (CMO) until 1956), which belongs to the Ministry of Land, Infrastructure and Transport, has the responsibility for nationwide seismic monitoring and tsunami warning.

\section{Periodization of Japanese history and historical documents}

All raw materials used for investigating history are called shiryo (historical sources) in Japanese. Therefore, in principle, shiryo includes not only written documents such as chronicles, books, letters, diaries, memoirs and notes but al- so epigraphs, paintings, drawings and all kinds of relics, remains and folklore. Conventionally, however, the word shiryo is used to mean written historical documents, which is the case in historical seismology as well.

The documents are commonly grouped by major periods in Japanese history (fig. 4) and in each period spatial coverage of written historical records depends upon the location of a political and cultural center, usually the capital. During the Kofun (or Yamato) period (ca. A.D. 300-710), the Yamato clan rulers in southwest Japan established the Imperial line that continues with today's Emperor. In the Asuka and Hakuho sub-periods of the late Kofun period Imperial Palaces were located mostly in the Asuka region, 55-60 km south of present-day Kyoto (see fig. 9a). In the beginning of the Nara period (710-794), the Imperial Court established Japan's first permanent capital at Heijokyo (later called Nara, about $35 \mathrm{~km}$ south of Kyoto; see fig. 9a) modelled on the Chinese capital. In the ensuing Heian period (794 to 1185 or 1192) the capital had been moved to Heian-kyo (later called Kyoto; figs. 1, 9a), which had remained the home of the Imperial Court until 1868. With a shift in power from the Imperial Court to a military government in $\mathrm{Ka}$ makura, about $45 \mathrm{~km}$ south of present Tokyo (see fig. 9a,b), the Kamakura period (1185 or 1192 to 1333) began. Following that period another military government ruled mainly from Kyoto during the Muromachi period (13331568). Since around 1467 the period of civil war had covered the whole country for a century and central government had been disintegrated. Although these times of devastation came to a close around 1600 through the reunifying process in the Azuchi-Momoyama period (1568 or 1573 to 1600 or 1603 ), preservation of historical records of the Medieval ages is considerably poor and many historical documents of older times are inferred to have been lost. Finally, the Tokugawa clan gained hegemony over other feudal houses, and the Tokugawa shogunate ruled Japan from Edo (now Tokyo; figs. 1 and 9a,b) between 1603 and 1867, the Edo period. Thereafter, with the Meiji Restoration of 1868, Tokyo became both the political and the Imperial capital, as it is today. 


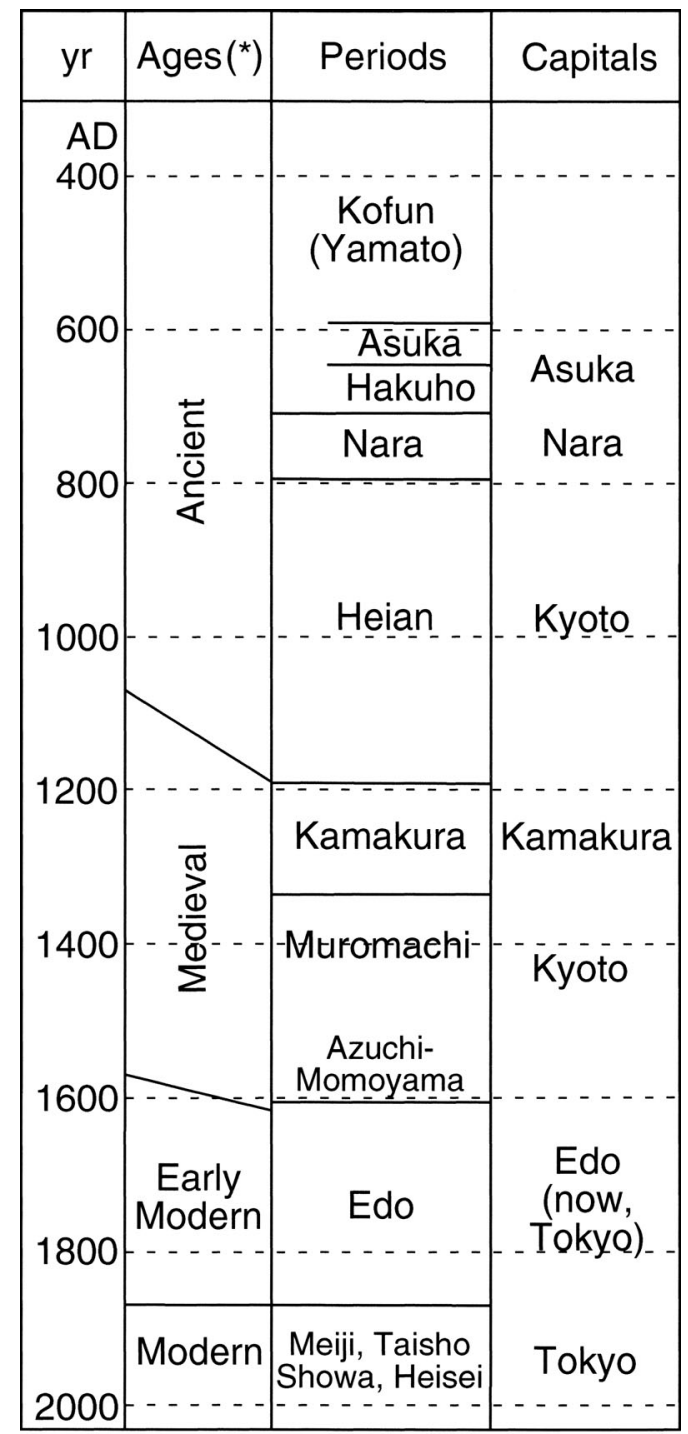

$\left(^{\star}\right)$ westernized period

Fig. 4. Periodization of Japanese history and capitals.

Japan's earliest documents originated during the Asuka, Hakuho and Nara periods. At that time, the power of the Imperial government had been strengthened and the centralized regime based on elaborate legal codifications following the Chinese system had been estab- lished. By the early part of the Heian period, Rikkokushi (Six National Histories; including aforementioned Nihon Shoki) (e.g., Kuroita, 1934b,c, 1935, 1951, 1952), strictly official histories written in classical Chinese, had been compiled by court functionaries at the Emperors' command.

The last of the six was completed in 901. Rikkokushi covers the mythology and Japanese history since the earliest times to 887 based on records kept by the court, leading families, and temples. The descriptions are basically reliable except for the myths and legends in the early part of Nihon Shoki. Included are many records of earthquakes, tsunamis and volcanic eruptions. Although the writers were based in the vicinity of Asuka, Nara and Kyoto, they described large-scale earthquake disasters in places far from Kyoto, such as Kyushu (in 679), Kanto (district around present Tokyo; in 818, 841 and 878) and farther north except for Hokkaido (in 830 and 850 in northwest Honshu and in 869 east off northern Honshu) (for these events, see fig. 9a,b).

The oldest earthquake catalogue in Japan, though non-scientific of course, is the section of earthquakes in Ruiju Kokushi (Classified National History) (e.g., Kuroita, 1933b, 1934a) compiled by Sugawara no Michizane (845903), an eminent court scholar, and completed ca. A.D. 900. In Ruiju Kokushi matters recorded in Rikkokushi are re-edited by classifying them into various categories. Although the existing copy of Ruiju Kokushi is less than one third of the original, the section of earthquakes survives. As a chronology of about 700 earthquakes before 887 , it is invaluable because it mentions events from parts of Rikkokushi that have been completely lost.

Since Rikkokushi, Japan has had no official national histories in the strict sense. Historical source materials after 887 are various chronicles compiled by scholars, temples, feudal lords and military governments; fragmentary records and diaries of the Imperial Court, temples, shrines and military rulers; and diaries, biographies, essays and letters of court nobles, priests and warriors. Since after the middle of the Heian period until the end of the Edo period, many diaries were written by court nobles and 

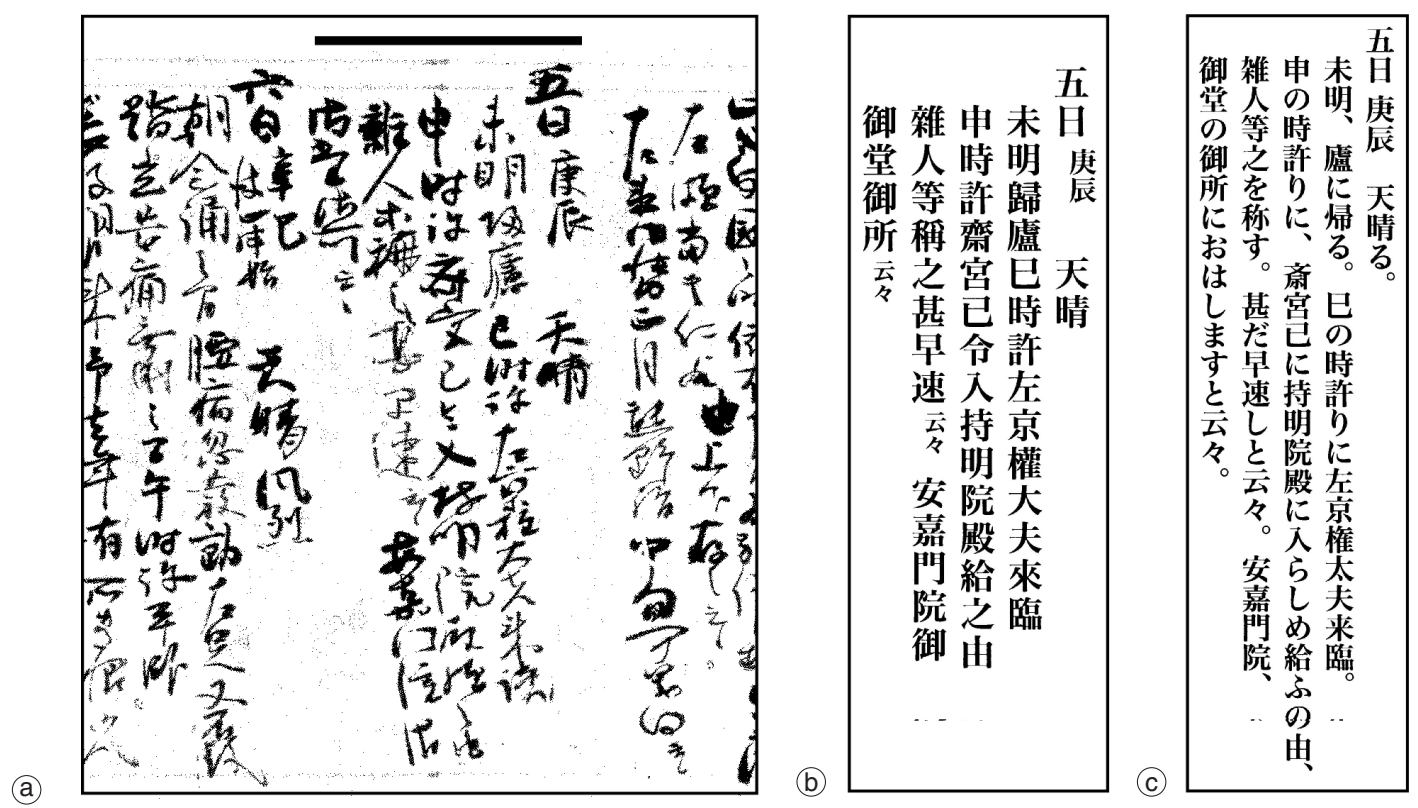

Fig. 5a-c. Meigetsuki, diary of Fujiwara no Sadaie (1162-1241), a court noble and a great poet, as an example of Japanese historical documents. a) Photo of the national treasure original script (reproduced from Reizeike Shiguretei Bunko (2003) by courtesy of Reizeike Shiguretei Bunko). The bar in the upper part indicates the part of the 5th day of the 2nd month of the 1st year of Tenpuku (17 March 1233 in the Julian calendar), which is referred to in Section 7.3 of the text. b) Faithful reprint of the bar-indicated part in (a) by types. Note that this diary is written in Chinese, which is rather usual in the Ancient and Medieval ages. c) Type print of the Japanese reading of (b) by the combination of kanji (Chinese character) and kana (Japanese alphabet). The sentences are still archaic style and rather difficult for modern Japanese people to understand.

priests in and around Kyoto, and many of them survive mostly in forms of hand written copies. For some of them, however, the original scripts have been preserved as national treasures. Figure 5a-c shows one example, which is referred to in Section 7.3.

After the age of Rikkokushi, events in northeast Japan, including the present Tokyo metropolitan area, were sparsely recorded before the Edo period, except during the Kamakura period. The Kamakura shogunate compiled Azuma Kagami (e.g., Kuroita, 1932, 1933a) as its official history from 1180 to 1266 , which contains many records of earthquakes.

During the Edo period of long-term peace and stability, economic and cultural developments of
Japan created mountains of primary documents, not only in the ruling class but also among the commoners of burgeoning cities and taxed villages. These documents include official histories, records and diaries of the Tokugawa shogunate; histories, chronicles, records and diaries of 250or-so regional lords; numerous records, memoranda, letters and diaries by urban merchants and leading farmers in villages; and private writings of various kinds among the ruling warrior class.

Because of national isolation under the Tokugawa shogunate, Japan had little contact with the West except for The Netherlands for more than two centuries during the Edo period and left behind the progress of modern science and technology. Instead, however, bibli- 
ography, historiography, national and local history had been highly developed, many Ancient and Medieval documents were transcribed or published in wood-block prints, and thus rather plentiful high-quality data had been prepared for the historical research that followed the Meiji Restoration.

Thus, an enormous quantity of historical documents is available throughout Japanese history. However, the spatial and temporal record densities are very inhomogeneous. While seismologists tend to discuss tectonic reasons for the remarkable temporal change in seismicity as is shown in fig. 6 , such as the nationwide high seismicity in the 9 th century, the apparent temporal variation in seismicity is basically a faithful reflection of the historical source inhomogeneity explained so far.
In 1963-1976 Kokusho So-mokuroku (Allinclusive Catalogue of Japanese Writings; in nine volumes)(Morisue et al., 1936-1976) was published by Iwanami Shoten Publisher in Tokyo. It was the results of a nationwide census of historical documents that was made with the cooperation and assistance of the country's leading scholars since 1939. It catalogues more than 500000 books and writings written by Japanese since the earliest times of history to 1867 . Included is basic information on each entry: title (including the transliteration of potentially ambiguous Chinese characters), length or number of volumes, classification by document type, author or editor where known, date of completion, the various manuscripts or printed editions, and the libraries, archives, temples and private houses
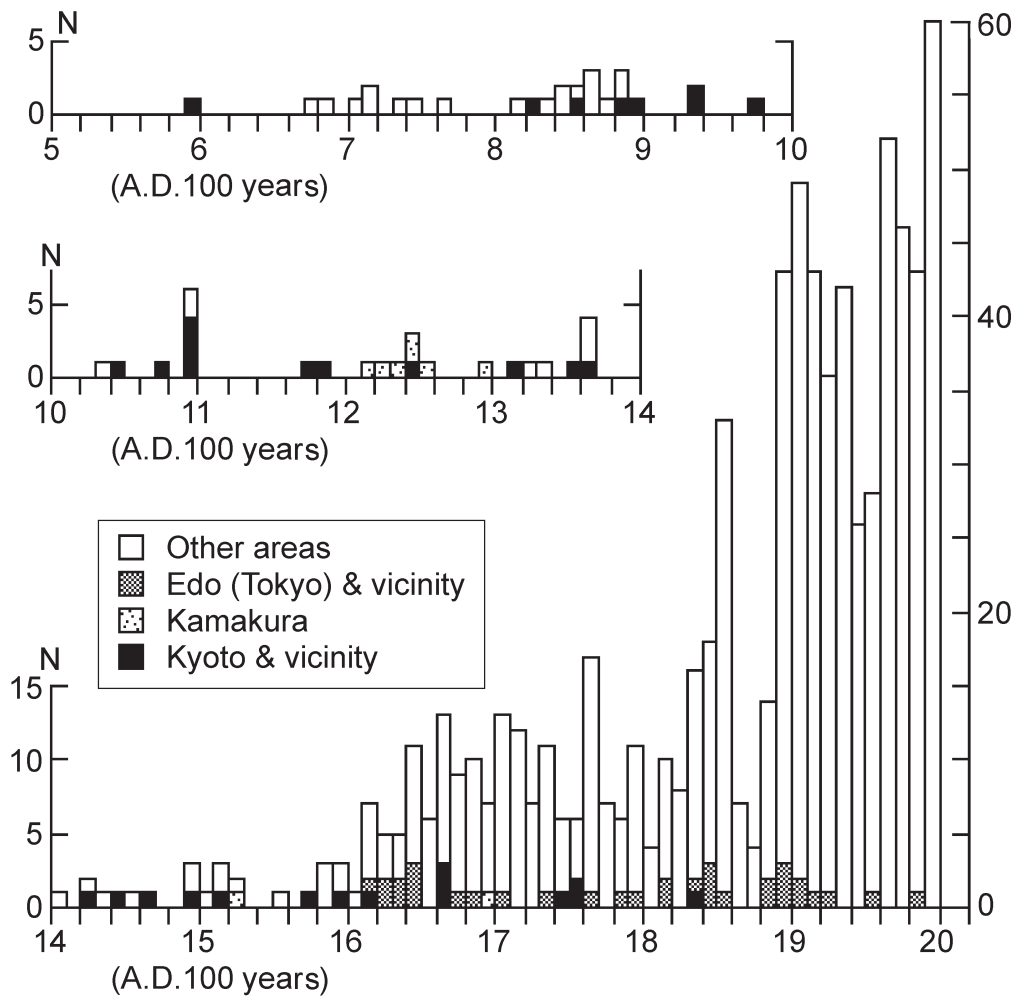

Fig. 6. Number of destructive earthquakes in every ten years since A.D. 590 through 1999 in Kyoto and vicinity, the Kamakura area, the Edo (Tokyo) area and other areas in Japan based on table 3-1 in Usami (2003). 
where they can be found. This is an indispensable tool for historical sciences of Japan including historical seismology.

Today, most major historical source materials, especially in the Ancient and Medieval ages, are available in type-printed books published through careful and critical collating with the most reliable extant copies.

\section{Brief history of historical seismology in Japan}

\subsection{Dawning of seismology}

In 1854 Japan was forced to open its door to the West by successive demands by the United States, Great Britain and Russia. Ensuing political convulsions brought down the Tokugawa shogunate; a new Imperial government was formed in the Meiji Restoration of 1868. The new government spurred rapid modernization, or Westernization, under the slogan of «enrich the country and strengthen the military». Importing and promoting Western science and technology became national mandates. Japanese seismology began in this context.

Early in Meiji era (1868-1911), the Japanese government invited Western experts to work as advisors or teachers in various fields. Some in science and engineering were surprised by and became much interested in the frequent earthquakes felt in Tokyo. These circumstances promoted efforts to measure earthquake ground motion accurately by instruments and to learn about the space-time distribution of past earthquakes in the Japanese Islands. By chance, on 22 February 1880 the Yokohama earthquake of $M$ 5.5-6.0 took place causing slight damage in Yokohama (roughly $30 \mathrm{~km}$ south-southwest of Tokyo) and Tokyo, and the Seismological Society of Japan, the world's first academic society of seismology, was established on April 26 in that year.

Around this time the first scientific studies on earthquake history in Japan were published by Hattori (1878), a Japanese, Naumann (1878) and Milne (1881) (see Usami, 1979, 1988, 2002b). A little later, apart from them, Ogashima Hatasu, a government official in mining, edited without any help a set of comprehensive chronological tables of 13 kinds of natural disasters in Japan since ancient times to 1885 including earthquakes and volcanic eruptions. After his death at age 35, it was published as a book (Ogashima, 1894) that had been conveniently referred to for a long time because it contains original records. Here, we should note that most data used for all these works had been well prepared in the Edo period as mentioned in the previous chapter.

\subsection{Compilation of historical earthquake documents}

In 1892 the Imperial Earthquake Investigation Committee (direct translation of the Japanese name is Board of Investigation for Preventing Earthquake Disaster) was established with the 1891 Nobi earthquake, a great inland event of $M_{J}$ (magnitude assigned by JMA; see Section 5.6) 8.0 in central Japan with more than seven thousand dead, as a momentum. One of the 18 purposes of the Committee was to investigate historical earthquakes and to compile earthquake history. Tayama Minoru was appointed as a part-time member of the Committee for compilation of historical earthquake records. In 1904 the achievements of his efforts was published from the Committee as Dai-Nihon Jishin Shiryo (Collection of Historical Documents on Earthquakes in Great Japan) (Tayama, 1904a,b) in two volumes with an attached earthquake catalogue (Tayama, 1904c). Then, Omori $(1913,1919)$ made descriptive catalogues of Japanese large earthquakes.

Concerning this work, only efforts on the seismology side have been explained so far (e.g. Usami, 1979, 1988, 2002b). However, it should be emphasized that the work must have owed very much to the national project of collecting and compiling all historical documents in Japan after Rikkokushi thoroughly, and this project, again, was indebted a great deal to the historiographical fruits during the Edo period. Tayama was, at the same time, a non-regular member of Shiryo Hensan-kakari (Department of Compilation of Historical Materials) attached to the College of Literature of Tokyo Imperial University (now, Historiographical Institute (HI) of the 
University of Tokyo) which has been continuing compilation and publication of Dai-nihon Shiryo (Collection of Historical Documents in Great Japan) (Historiographical Institute of the University of Tokyo, 1901-) as the national project. In a sense, Dai-nihon Jishin Shiryo is a part of Dai-nihon Shiryo, which basically followed Shiryo (Historical Materials), unpublished manuscripts in the late Edo period edited by Hanawa Hoki'ichi, a great scholar on Japanese classics blind from the age of five, by the support of the Tokugawa shogunate.

Based on Tayama (1904a,b), Omori (1913, 1919) and other investigations on historical and post-1872 earthquakes, Imamura (1925) made a compact «Chronological Table of Large Earthquakes in This Country» which was contained in Rika Nenpyo (Chronological Scientific Tables) No. 1. Although the Table gave only occurrence dates in the Japanese and Western calendars, names of damaged places and brief descriptions of damage for 312 earthquakes including Korean and Formosan ones, a map showing epicenters of 82 events was attached. This Rika Nenpyo and the Chronological Table of Large Earthquakes in Japan have been published every year since then, except for 19441946 during World War II. The Table has been revised and updated by several seismologists from time to time and widely referred to.

\subsection{Enrichment of historical seismology}

The 1923 great Kanto earthquake of $M_{w} 7.9$, which caused more than 140000 deaths in Tokyo and vicinity, spurred the founding of the Earthquake Research Institute (ERI) of Tokyo Imperial University. It was established in 1925 , replacing the Imperial Earthquake Investigation Committee.

In 1928 Musha Kinkichi, a high-school geography and English teacher, was asked by the director of ERI to revise and enlarge Tayama's (1904a,b) Dai-nihon Jishin Shiryo. Musha devoted himself to this avocation enthusiastically with almost no direct help or financial support. In a very difficult situation during World War II his accomplishment was published in mimeographs as three volumes of Zotei Dai-nihon
Jishin Shiryo (Collection of Historical Documents on Earthquakes in Great Japan, Enlarged and Revised Edition) in 1941 and 1943 by the support of the Japan Society for the Promotion of Science (Musha, 1941, 1943a,b). The fourth volume was published after the end of World War II in 1945 by the help of Mainichi Newspapers Company as Nihon Jishin Shiryo (Collection of Historical Documents on Earthquakes in Japan) (Musha, 1951).

Imamura (1937) made another map of epicentral distribution of large earthquakes in Japan (fig. 7) based on the table of severe earthquakes during 1596-1935 prepared by himself. It is noteworthy that in this map epicentral areas are shown for larger earthquakes instead of epicentral points. We can see from this map that the major seismic belts in and around Japan had been already recognized by Imamura.

A remarkable fruit of historical seismology in Japan in the 1930's and 1940's is the forecasting of great Tokai and Nankai earthquakes, which will be described in Section 7.1, made by Imamura (1933, 1943). Imamura had understood correctly the characteristics of recurrence of

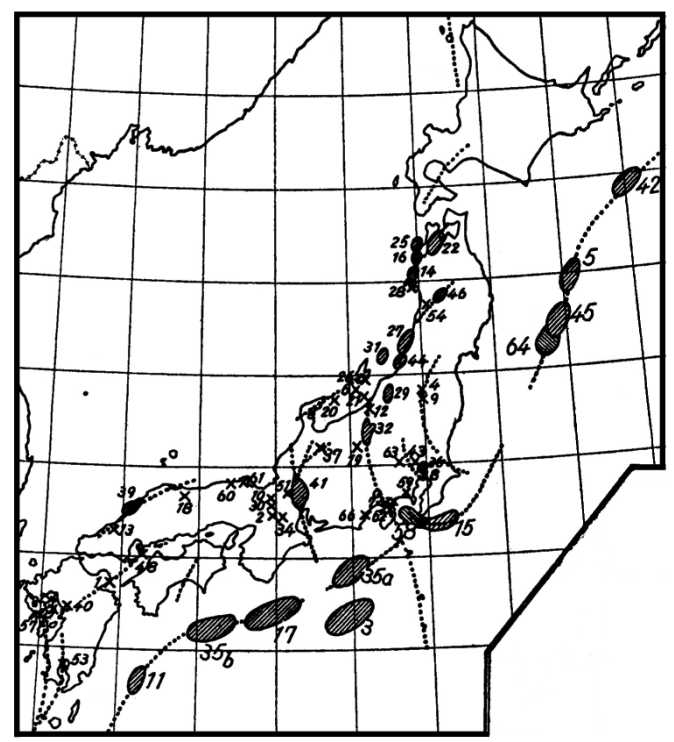

Fig. 7. Epicentral distribution of severe earthquakes in Japan since 1596 till 1935 as given by Imamura (1937, fig. 80). 
great earthquakes along the Pacific coast of southwest Japan, which is now explained as due to the subduction of the Philippine Sea plate, based on the study of historical earthquakes and contemporary interseismic and past coseismic crustal deformations. Imamura considered that the Tokai and Nankai earthquakes were imminent and asked the authority concerned to conduct repeated precise leveling surveys along a new line in the Tokai district and founded a crustal activity observatory for seismic and tidegauge observations in the Kii Peninsula (see fig 11) at his own expense. On 7 December 1944 the Tonankai earthquake (western half of the Tokai earthquake; see fig. 11) of $M_{w} 8.1$ took place causing more than 1000 deaths and missing persons. The leveling survey near the epicentral region was just being carried out at the time of the earthquake, and the probable short-term precursory vertical crustal movement was detected. Imamura judged that the Nankai earthquake would follow soon and urged the persons concerned to make every effort to realize short-term prediction. However, due to the shortage of materials by the complete defeat of World War II, observations could not be made sufficiently, and on 21 December 1946 the Nankai earthquake of $M_{w} 8.1$ occurred causing more than 1400 deaths and missing.

Kawasumi (1951) presented a catalogue of 342 large earthquakes in Japan from A.D. 599 to 1949, which gave for the first time estimated epicenter coordinates (latitude and longitude in 0.1 degree) and magnitudes for most events. The magnitudes were Kawasumi's (1943) magnitude $M_{k}$, which was defined as the JMA seismic intensity at an epicentral distance of $100 \mathrm{~km}$. Kawasumi (1951) derived an empirical formula for obtaining Richter magnitude $M$ from $M_{k}$ as

$$
M=4.85+0.5 M_{k} .
$$

Richter magnitudes thus obtained for historical earthquakes were first printed in the table in $R i$ ka Nenpyo in 1952 by Kawasumi's editing.

\subsection{New trends}

Around the mid-1970's, historical seismology in Japan started to make more progress.
Ishibashi (1987) summarized marked tendencies of new trends as follows:

1) A huge amount of historical earthquake documents of high qualities which had been unknown to seismologists has been intensively collected from all over the country and published elaborately.

2) Interdisciplinary collaboration among seismologists, geologists, geomorphologists, and, especially, historians increased.

3) Critical reading of historical earthquake documents, minute inquiries into historical backgrounds at the times of earthquakes, efforts to evaluate seismic intensities from historical descriptions as objectively as possible, and quantitative treatment of seismic intensity data for estimating proper epicenters and magnitudes.

4) Methods of paleoseismology such as geological and geomorphological investigations of fault displacements, uplifted marine terraces, tsunami deposits and archaeological remains have been effectively applied.

5) Deduction of fault models, inference of fault segments which generated particular earthquakes, seismotectonic interpretations and discussions related to or focusing on long-term earthquake predictions were made actively.

Concerning the above-mentioned item (1) work of collecting new historical documents on earthquakes was re-started by Usami Tatsuo at ERI in 1970's. In 1976 because of the Suruga Bay earthquake hypothesis (Ishibashi, 1976, 1981), which claimed that a $M 8$-class interplate Tokai earthquake in the Suruga Bay region might be imminent, the importance of historical records of earthquakes aroused great public attention and the Ministry of Education made a special arrangement of cooperation between ERI and HI of the University of Tokyo (Usami, 1979). In 1979 the collecting work of historical earthquake documents was put in the 4th five-year plan of the National Earthquake Prediction Program. The collected documents were published as Shinshu Nihon Jishin Shiryo (Historical Documents on Earthquakes in Japan, New Collection) (Earthquake Research Institute of the University of Tokyo, 19811994). Tsuji Yoshinobu, at National Research Center for Disaster Prevention at the time, also 
collected historical earthquake documents very energetically after the Tokai earthquake issue mainly in the region affected by the Tokai and Nankai earthquakes with special interest in historical tsunamis. He edited six thick volumes of newly collected historical documents (e.g., Tsuji, 1979a,b), but all the contents have now been absorbed in Shinshu Nihon Jishin Shiryo.

Beginning with the second volume in 1982, the volumes of Shinshu Nihon Jishin Shiryo were published by the Japan Electric Association (JEA). This association serves the electric industry in Japan. It provided funding for publication of Shinshu Nihon Jishin Shiryo in the absence of support from the National Earthquake Prediction Program. According to JEA, the association has been carrying out investigation of historical materials on earthquakes since 1981 under the leadership of Usami (Usami and Daiwa Exploration \& Consulting Co. Ltd., 1994). For the electric-power industry, historical earthquakes are important in site selection and seismic design of nuclear power plants. Because Japan's national energy policy mandates the development of nuclear power, the country has 52 operating reactors among 16 commercial nuclear power stations, all along coastlines, and additional plants are planned or under construction. Thus, although most Japanese seismologists seem to be unaware of the situation, historical seismology in Japan owes much to financial support by the country's nuclear power development policy and to the resulting industry.

In the late 1970's a small interdisciplinary research group of ko-jishin (old earthquakes, paleo-earthquakes) started up activity. It continued detailed critical studies on selected historical earthquakes contained in Rika-Nenpyo's Table and Usami's $(1975,1987)$ books (Hagiwara et al., 1982, 1989, 1995). On the other hand in 1984 the first informal meeting of research group of rekishi-jishin (historical earthquakes) was held. The meeting, in which anyone interested in historical earthquakes could talk, had been held every year and collection of presentations had been published in annual bulletin Rekishi-jishin. In 2000 the group was reformed to a membership system of Rekishijishin Kenkyu-kai (The Society of Historical Earthquake Studies).
The tragic disaster with more than 6400 deaths due to the 1995 Kobe earthquake $\left(M_{J} 7.3, M_{w} 6.9\right)$ changed the national regime of earthquake investigation, earthquake disaster mitigation and earthquake prediction research drastically. Very dense networks of high-sensitive, or broad-band, or strong-motion digital seismometers and GPS stations have been deployed, investigation of active faults and research on strong ground motion have been greatly intensified. Historical seismology, however, has not been included in this intensification. This is probably because the real situation of Japanese historical seismology is not well understood by most seismologists and the authority concerned; many people may have imagined that historical earthquake investigation had been completed with Usami's (1987, 1996) catalogues.

\section{Methodology of historical seismology in Japan}

Historical seismology is seismological observation and analysis of historical earthquakes not by seismograms but by historical materials. There are two main objectives in this study. One widely accepted, is to reconstruct historical seismicity in the study area finally establishing historical earthquake catalogues. The other, I would like to emphasize, is to widen the observation time window of seismology to look for new seismic phenomena which are scarcely observed within the current very short instrumental period. Therefore, although the basic knowledge of modern seismology is an indispensable background of historical seismology, we should be free from a conventional view of current seismology; in older times extraordinary phenomena may have happened. In this sense historical seismology is full of dreams for younger seismologists.

Historical seismology is an integration of historiography and earthquake science. The procedure of observing and elucidating a certain historical earthquake is as follows (Ishibashi, 1995b).

1) Collecting all available historical documents on the target earthquake by judging that 
each document describes the same event of the same occurrence time

2) Rejecting unreliable records by careful and critical examination of each document from the viewpoint of historiography

3) Extracting historical facts on the earthquake by reading and examining selected records very carefully from the both viewpoints of historical and earthquake sciences

4) Revealing true earthquake effects such as ground motion, coseismic crustal movement, surface rupture, tsunami, felt aftershocks and so on from the extracted historical facts in terms of earthquake science

5) Obtaining a seismological summary of the earthquake including origin time (date and time), magnitude, seismic intensity distribution, epicenter or epicentral area, focal depth, fault model, rupture process, and seismotectonic implication through seismological interpretation of revealed phenomena.

In Japan, step (1) has been pursued intensively for all historical earthquakes since the beginning of historical seismology as explained in the preceding chapter. Step (2), on the contrary, has been paid no attention to at all in the mainstream, although several researchers have come to consider this step seriously in recent years. Neither has step (3) been performed rigorously. Concerning steps (4) and (5), although they have been more or less conducted for all historical earthquakes, the conventional procedure has not necessarily been systematic among researchers. Under all these circumstances there still remain various errors as mentioned later even in the latest catalogue of historical earthquakes. And there are some problems peculiar to Japanese historical seismology as follows.

\subsection{Calendar and dates}

Until the Gregorian calendar, a solar calendar being used worldwide, was adopted on 1 January 1873 (the 3rd day of the 12th month of the 5th year of Meiji; Usami's (1979) description is incorrect), the Japanese had been using a lunar calendar. The feature of the traditional Japanese lunar calendar, essentially different from the Western solar calendar, is a close cor- respondence between civil and natural months and an inexact correspondence between civil and natural years.

In historical seismology in Japan dates of occurrence of earthquakes are usually converted into the solar calendar. But, one problem exists that almost all works in the Japanese historical seismology so far, including Musha's (1941, 1943a,b, 1951) and Usami's (1975, 1987, 1996, 2003) books and the catalogues in Rika-nenpyo, have adopted the Gregorian calendar throughout historical times, whereas the Julian calendar had been officially used until 4 October 1582. Hayakawa and Koyama (1997) and Koyama and Hayakawa (1998) pointed out this problem and recommended using the Julian calendar before October 1582 because of the importance of global study of large-scale volcanic eruptions, tsunamis and earthquakes. Ishibashi (1998b,c, 1999b), for example, followed this recommendation. Utsu (1990) had already adopted the Julian calendar before this recommendation. However, Usami's (2003) catalogue, which is regarded as the most authoritative one in Japan, does not use the Julian calendar, which Usami (1986) regards as less convenient than simply applying the Gregorian calendar throughout Japanese earthquake history.

Era names (nengo or gengo) determined by Emperors have been used in Japan continuously since 701 up to now following the old Chinese system. While some Emperors reigned under only one era name, especially since 1868 Emperors Meiji, Taisho, Showa and present Heisei, most Emperors in older times changed era names rather often during their reigns for various superstitious reasons, in which large-scale earthquake disasters were important. Before Taisho a new era name was applied to the whole calendar year during which the change was made. For example, great interplate Tokai and Nankai earthquakes took place successively on the 4th and 5th days of the 11th month of the 7th year of Ka'ei (23 and 24 December 1854) devastating almost the western half of Japan and the era name was changed from Ka'ei to Ansei on the 27th day of that month; then the earthquakes have been called the Ansei earthquakes or Ansei Tokai and Nankai earthquakes.

Since almost all era names are written with two Chinese characters and some of them re- 
semble each other, low-quality historical documents sometimes have errors in writing. For example, on the 4th day, 10th month, 4th year of Ho'ei (28 October 1707) the great Ho' ei earthquake occurred along the Pacific coast of southwest Japan causing catastrophic disasters; several documents contained in Musha (1941) describe that a large earthquake took place on the same date of the 4th year of Kan'ei (11 November 1627), which can be judged to be mistakes between Ho'ei and Kan'ei by careful examination. We should note, however, it is difficult to know such a mistake if the number of documents is not enough to judge. Japanese people have been using a sexagenary cycle (kan-shi) to enumerate years and days following the Chinese classical system, which was used very commonly in the period of historical earthquakes. The system is the combination of 10 stems (kan) and 12 branches (shi), each of which is represented by one particular Chinese character, and the cycle repeats every 60 years; for example, the 4th year of Ho'ei (mostly 1707) was the year of tei-gai, and the next teigai year was the 4th (this 4th is just a coincidence) year of Meiwa (mostly 1767). This system is helpful in checking the reliability of historical records by examining, for example, the self-consistency of the expression of the year.

\subsection{Time of day}

The Japanese system for telling the time of day was completely different from the present one before the adoption of the solar calendar in 1873. There were two different systems. One divided a day into 12 even parts and assigned 12 branches of the sexagenary system. The other divided the periods from sunset to sunrise and from sunrise to sunset into six equal parts, respectively; the duration of one part is different between daytime and at night even on the same day and different according to seasons. In the Ancient and Medieval ages the former equally-dividing system was officially used in the Imperial Court, but in the Edo period the latter unequally-dividing system was commonly used. Often, one part of roughly two hours was divided into two or three intervals.
According to Nihon Shoki, a kind of water clock made by the Emperor was used in 671 for the first time as the standard for telling time to people. It is said that a Western mechanical clock was first introduced to Japan in 1551; Francisco de Javier, a Jesuit missionary, presented it to a feudal lord in the western Honshu. A small number of pendulum clocks of Huygens' invention in the latter half of the 17th century were brought into Japan during the national isolation in the Edo period, and based on them original pendulum clocks compatible with the unequally-dividing time system were developed. They were used among upper classes in the late Edo period. Commoners, however, knew time by their own sense or by hearing bells or drums sounded in castles, temples or special towers in towns, whose time control was not accurate.

In any case, the timing system for the Japanese historical earthquakes is not good; the error may exceed about 30 minutes for the occurrence time of an earthquake even in the best condition. The beginning of a new day, midnight or dawn, was not standardized in historical times, so we should be careful in identifying the date from historical records.

\subsection{Place names}

Since Japan has not experienced complete occupation by foreign countries except after World War II, there is no significant problem of drastic change of place names. Of course many place names have been changed since ancient times, but scholars and dilettantes have investigated this matter minutely, especially since the Edo period, and now we have many excellent dictionaries of place names. A recent major problem is that small place names in local communities have been vanishing rapidly in the last few decades, which makes it very difficult to know from historical records, for example, how far into a certain village a historical tsunami reached.

\subsection{Seismic intensity scale in Japan}

In Japan a seismic intensity scale was first introduced in 1884, which was a four-degree 
Table I. JMA seismic intensity scale 1949.

\begin{tabular}{cl}
\hline \hline Scale & Explanation \\
\hline 0 & No feeling. Shocks too week to be felt by humans, registered only by seismographs. \\
1 & $\begin{array}{l}\text { Slight. Extremely weak shocks felt only by persons at rest or by those who are very sensitive to earth- } \\
\text { quakes. }\end{array}$ \\
2 & $\begin{array}{l}\text { Weak. Shocks felt by most persons, slight shaking of doors and Japanese sliding doors (shoji). } \\
3\end{array}$ \\
$\begin{array}{l}\text { Rather strong. Slight shaking of houses and buildings, rattling of doors and Japanese sliding doors } \\
\text { (shoji). The water surface of a vessel can be seen to ripple. }\end{array}$ \\
$4 \quad \begin{array}{l}\text { Strong. Strong shaking of houses and buildings, overturning of unstable objects, and spilling of liquids } \\
\text { out of vessel. Felt by walking people outdoors, and many people inside rush outdoors. Considerable } \\
\text { swinging of hanging objects such as light bulb. }\end{array}$ \\
5 & $\begin{array}{l}\text { Very strong. Cracks in the walls, overturning of gravestones, stone lanterns etc., damage to chimneys } \\
\text { and stone fences. }\end{array}$ \\
6 & $\begin{array}{l}\text { Disastrous. Collapse of less than } 30 \% \text { of all houses, landslide, and fissures in the ground. Most people } \\
\text { cannot stand. }\end{array}$ \\
7 & $\begin{array}{l}\text { Very disastrous. Collapse of more than } 30 \% \text { of all houses, intense landslide, large fissures in the } \\
\text { ground, and faults. }\end{array}$
\end{tabular}

After Earthquake Research Committee, Headquarters for Earthquake Research Promotion, Prime Minister's Office, Government of Japan (1998).

\begin{tabular}{|c|c|c|c|c|c|c|c|c|c|c|}
\hline JMA & 0 & 1 & \multicolumn{2}{|c|}{2} & 3 & \multicolumn{2}{|c|}{4} & 5 & 6 & 7 \\
\hline MM & 1 & 2 & 3 & 4 & 5 & 6 & 7 & 8 & 9 & 101112 \\
\hline MSK & 1 & 2 & 3 & 4 & 5 & 6 & 7 & 8 & 9 & $10 \mid 1112$ \\
\hline
\end{tabular}

Fig. 8. Comparison among seismic intensity scales of JMA (of 1949; see text), MM (Modified Mercalli) and MSK (Medvedev-Sponheuer-Karnik) (after Seismological Division of the JMA, 1971).

scale (e.g., Seismological Division of the JMA, 1971). Through several changes since then, the JMA seismic intensity scale 1949 of eight degrees (table I) was adopted in 1949. Except for the maximum intensity, 7, which was added after the disaster of the 1948 Fukui earthquake $\left(M_{J} 7.1\right)$, this scale can be regarded as the same as preceding scales since around 1898.

On 1 April 1996 the definition of the JMA seismic intensity scale was changed; seismic intensity is to be determined based on the instrumental seismic intensity measured by special seismic intensity meters. Moreover, on 1
October 1996 intensities 5 and 6 were divided into two ranks, 5 Lower and 5 Upper, and 6 Lower and 6 Upper, respectively. In the Japanese historical seismology, however, we can consider that intensity evaluation has been done by referring to the JMA seismic intensity scale of 1949. The comparison between this scale and other scales used in the world is shown in fig. 8.

It is noteworthy that all local weather stations belonging to JMA (CMO until 1956), as well as many local offices assigned, have been reporting seismic intensity systematically since 
1885 and that the CMO/JMA has been publishing the data in bulletins. This is a valuable data set for historical seismology as well in that many examples of dense seismic intensity distributions are available for instrumentally located earthquakes all over Japan. Based on this data set Utsu (1989) compiled seismic intensity maps for large earthquakes $(M \geq 6)$ and damaging earthquakes in Japan for the period between 1901 and 1926.

Usami and Collaborators (1986) prepared a tentative table for evaluating seisimic intensi- ties for historical earthquakes during the Edo period based on various phenomena including damage of temples, shrines, stone walls, castles, cultivated fields, roads, bridges, and so on, but it has not yet been used by other researchers widely. The standard guidelines for estimating seismic intensity in the Ancient, Medieval and Early Modern ages of Japan have not yet been established, and for the same historical record the seismic intensity has been sometimes overestimated or underestimated according to researchers.

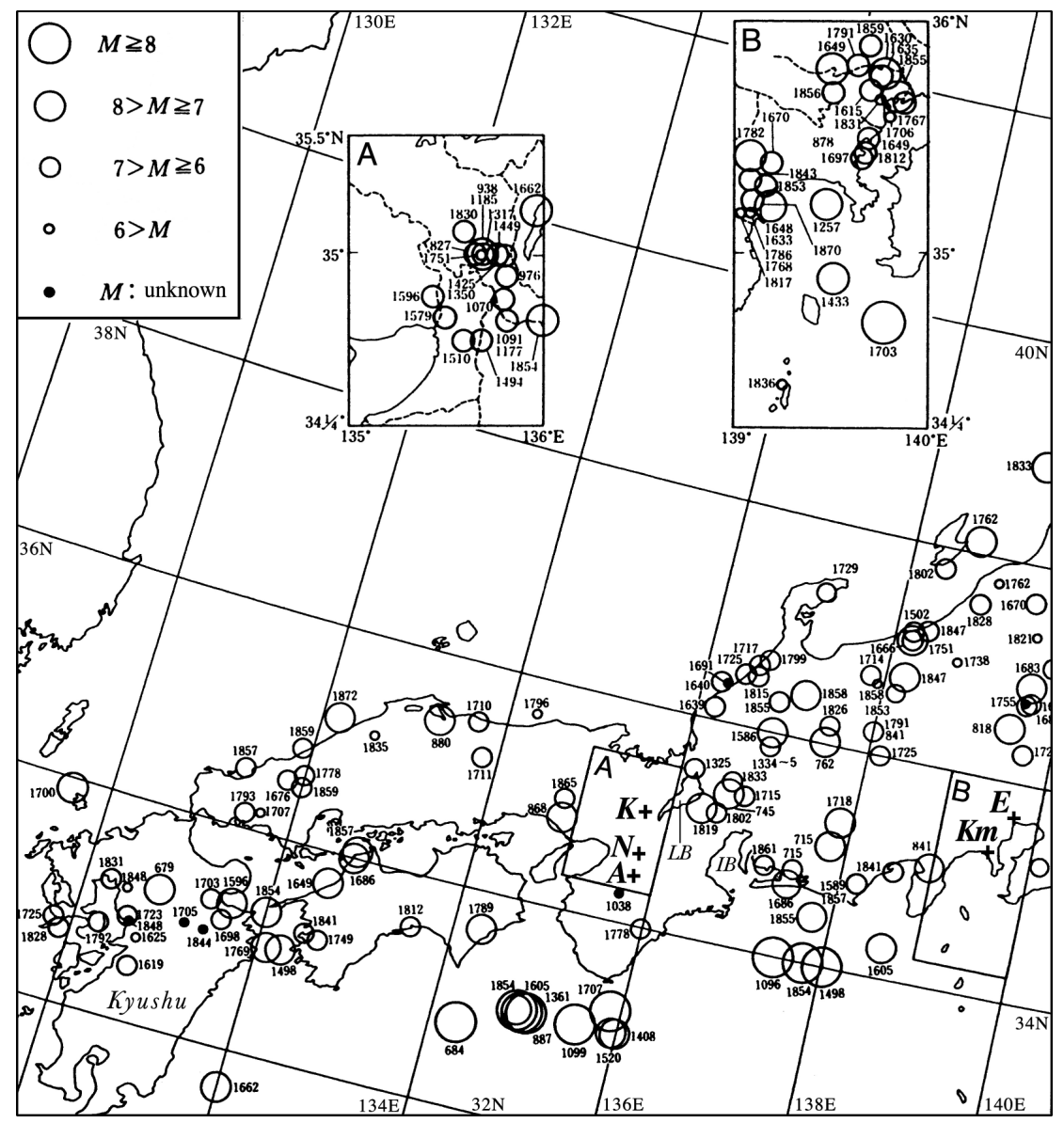

Fig. 9a. Epicentral distribution of destructive earthquakes in Japan since the beginning of history till 1872 shown in Usami (2003) (western part of Japan). Historical capitals have been added: $\boldsymbol{A}$ - Asuka; $\boldsymbol{N}$ - Nara; $\boldsymbol{K}$ - Kyoto; $\boldsymbol{K} \boldsymbol{m}$ - Kamakura; $\boldsymbol{E}$ - Edo (present Tokyo). Reproduced from Usami (2003) with slight modification by courtesy of the author. 


\subsection{Epicenters and focal depths}

Generally, epicenters of historical earthquakes in Japan have been given as macroseismic epicenters, centers of isoseismal maps, under an implicit assumption that focal depths were shallow. In many cases, however, this may not be the case because many large earthquakes in Japan occur at deeper places off the Pacific coast or within the Pacific and the Philippine Sea slabs. Recently, epicenters of historical earthquakes with some particular features have been estimated by comparing their features including isoseismal maps with those of instrumentally well-located earthquakes. For example, the 1772 earthquake in northeast Japan had been considered to be an offshore event of $M$ 7.4 in Usami (1975), but owing to the occurrence of the 1987 slab earthquake of $M_{J} 6.6$ with focal depth of $72 \mathrm{~km}$ just beneath the Pacific coastline of northeast Japan, Usami (1996) relocated the 1772 epicenter near the coastline (see fig. 9b) and changed $M$ to $6+3 / 4 \pm 1 / 2$ because the feature of the damage distribution of

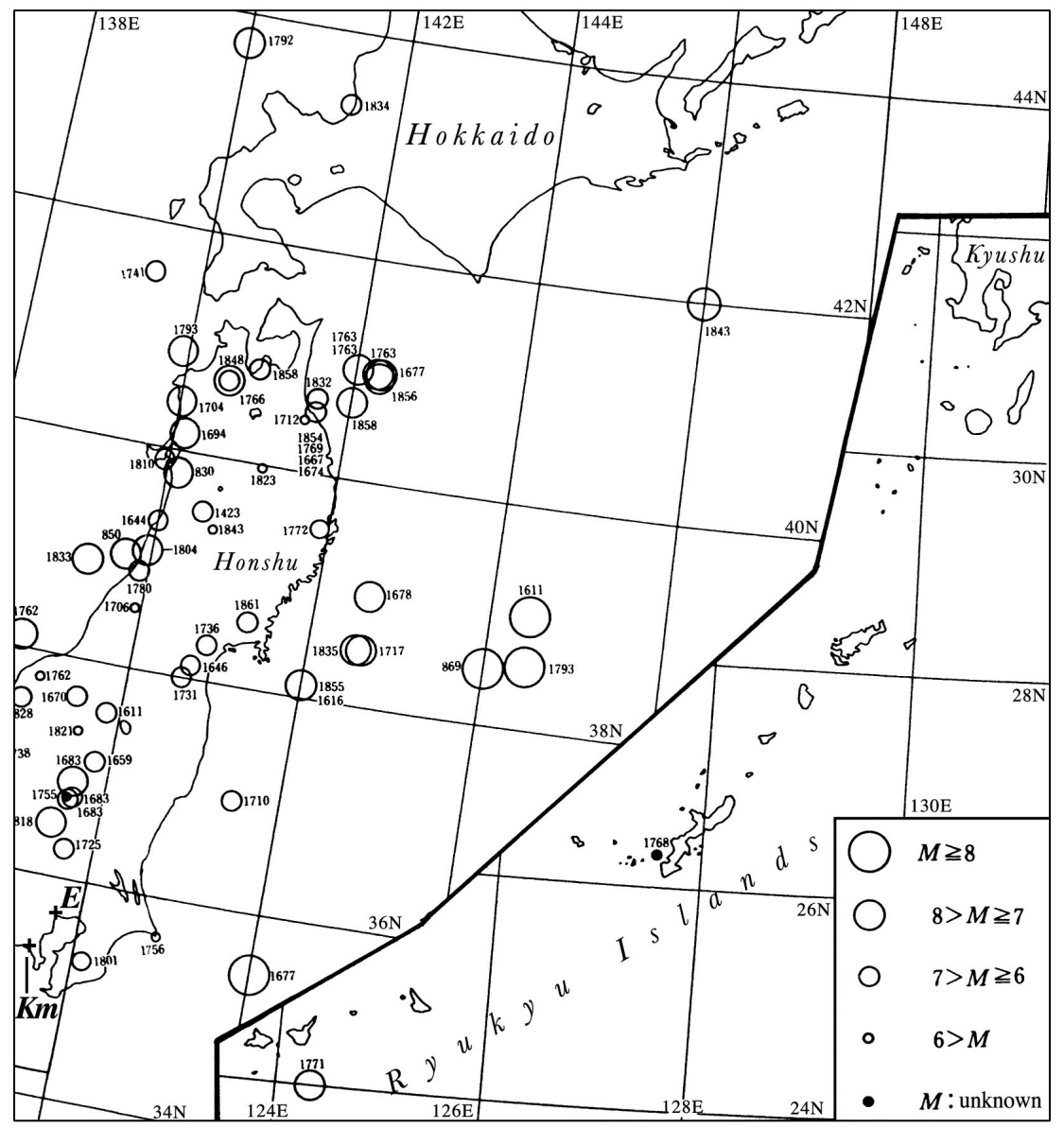

Fig. 9b. Epicentral distribution of destructive earthquakes in Japan since the beginning of history till 1872 shown in Usami (2003) (eastern and southwesternmost parts of Japan). Historical capitals have been added: $\boldsymbol{K} \boldsymbol{m}$ - Kamakura; $\boldsymbol{E}$ - Edo (present Tokyo). Reproduced from Usami (2003) with slight modification by courtesy of the author. 
the 1772 event resembles that of 1987 (Usami, 2002b, full $M_{S}$ ).

In some cases characteristics of ground motion such as predominant periods and duration times and presumable aftershock activities are also important for estimating earthquake types (see fig. 3) and hypocenter locations. One example is the 13 June 1648 earthquake. Usami (1987, 1996, 2002c, 2003) estimated its magnitude at 7.0 and epicentral coordinates at $139.2^{\circ} \mathrm{E}, 35.2^{\circ} \mathrm{N}$ (fig. $9 \mathrm{a}$ ), which is identical to those of the 1633 Kan'ei earthquake of $M$ about 7, one of disastrous Odawara, central Japan, earthquakes repeating every ca. 70 years (e.g., Ishibashi, 1985). Ishibashi (1978), however, inferred that the epicenter of this event was far away from Odawara, somewhere far offshore, based on the estimated seismic intensities at Odawara (5 Lower) and at Edo (4 Upper), absence of noticeable aftershocks and long-period ground motion at Edo revealed through critical and careful examination of historical records.

Another example is the 1819 Bunsei Ohmi, central Japan, earthquake of $M>7$ which caused severe damage to rather wide areas around Lake Biwa and north of Ise Bay (see fig. 9a). Though it had been implicitly regarded as a shallow crustal event and a causative active fault had been a main concern, Ishibashi (1999a) paid special attention to the fact that it had been accompanied with very few aftershocks; among 206 historical documents on this event, only two documents recorded two tiny earthquakes 10 days and 15 days after the main shock. Furthermore, by comparing the isoseismal pattern of this event with that of the 1994 May earthquake of $M_{J} 5.2$ which occurred at a depth of $44 \mathrm{~km}$ within the Philippine Sea slab beneath the Lake Biwa region, Ishibashi (1999a) inferred that the 1819 Bunsei Ohmi earthquake was a large slab event within the Philippine Sea plate subducted beneath central Japan.

Some researchers of historical earthquakes have inquired too closely into epicentral coordinates of great $M$ 8-class earthquakes, which is, however, almost meaningless because source regions of great earthquakes are as broad as $100-150 \mathrm{~km}$ in length, and epicenters or hypocenters, the points of initial break, can be hardly known from macroseismic data. For large or great earthquakes, estimation of source regions, or fault planes or asperity distributions if possible, is more meaningful. In this sense, Imamura's (1937) epicentral distribution map (fig. 7) shows his great prescience.

Earthquake Research Committee in Headquarters for Earthquake Research Promotion in Prime Minister's Office, Government of Japan (1998) shows estimated source regions for some large or great historical earthquakes.

\subsection{Magnitude of historical earthquakes}

At present, in principle, magnitudes of historical earthquakes in Japan are equivalent to $M_{J}$, magnitudes assigned by the Japan Meteorological Agency, which were introduced to give the same values as GutenbergRichter's magnitude (e.g., Utsu, 2002). Actually, however, a major problem is emerging from the history of researches (e.g., Hagiwara, 1989).

As mentioned in Section 4.3, Kawasumi, for the first time, assigned $M$ of historical earthquakes in the Table of Rika Nenpyo in 1952; $M$ converted from $M_{k}$ in Kawasumi's (1951) table. Meanwhile, it had been noticed that $M$ of about 3900 earthquakes in Japan during the period 1885-1943 obtained from $M_{k}$ and listed in a JMA's catalogue published in 1952 were unreasonably large, especially for events before 1914. Utsu (1979, 1982) examined in detail how and why these $M_{k}$ values were so strongly biased. Magnitude values of historical earthquakes which are basically based on $M_{k}$ should be re-evaluated.

On the other hand, many researchers have estimated magnitudes of specific historical earthquakes by means of the following formulas:

$$
\log S_{4}=0.82 M-1.0
$$

(Katsumata and Tokunaga, 1971)

$\log S_{5}=M-3.2$

(Muramatu, 1969)

$\log S_{6}=1.36 M-6.66$

(Muramatu, 1969) 
where $S_{I}$ denotes the area in $\mathrm{km}^{2}$ of JMA seismic intensity $I$ or larger. If we assume the area is circular with the radius $r_{I}$, then we can obtain the following formulas, which are more conveniently used:

$$
\begin{gathered}
\log r_{4}=0.41 M-0.75 \\
\log r_{5}=0.5 M-1.85 \\
\log r_{6}=0.68 M-3.58 .
\end{gathered}
$$

Magnitudes of Japanese historical earthquakes widely used now are mixtures obtained by several methods. Systematic re-examination is needed. Matsu'ura et al. (1999, 2000, 2001, 2002, 2003) carried out this kind of work for earthquakes after the late 16th century.

\section{Data and catalogues of historical earthquakes in Japan}

\subsection{Historical sources}

Among the collections of historical earthquake documents in Japan introduced in Section 4, Zotei Dai-nihon Jishin Shiryo and Nihon Jishin Shiryo compiled by Musha (1941, 1943a,b, 1951) and Shinshu Nihon Jishin Shiryo compiled by Usami and his colleagues (Earthquake Research Institute of the University of Tokyo, 1981-1994) are two main series for the current use. In principle, all historical documents describing earthquake-related matters in the Japanese Islands are thoroughly printed in these collections faithfully to original sentences. Therefore, if one has all these two collections of 25 volumes at hand, he or she can access all historical earthquake records in Japan without visiting any archives nor libraries.

Zotei Dai-nihon Jishin Shiryo and Nihon Jishin Shiryo, 4000 pages in total, added 6400odd earthquakes including 90 large events to their antecedents Dai-nihon Jishin Shiryo (Tayama, 1904a,b), which contained about 2000 earthquakes including 156 large events. Shinshu Nihon Jishin Shiryo, 21 volumes and 16812 pages in total, further added numerous earthquakes and historical documents.

There are, however, serious problems in these books. One is that probably the collection is not complete, especially for the Edo period. Hence
Usami, for example, is very enthusiastic in further searching for buried historical materials and publishing them (Usami, 1998, 1999, 2002a).

The second problem is much more serious than the first. They contain just fragments of historical documents, or clippings of descriptions of earthquakes only. And since the compilers did not carry out any critical examination of historical documents selection, they contain a mixture of reliable and unreliable records. Furthermore, no explanation of historical documents is given. Therefore, although they are valuable, we should regard them as a kind of index of historical records. Users should examine each historical document very carefully concerning the following points; by whom, when, where, in which situation and for what purpose was the document written, and how has it been handed down until today. And users should go back to the original document, see the whole text, and also examine historical backgrounds of descriptions. Checking contemporary reliable documents without earthquake description is also very important as will be shown in Section 7.3.

The third problem is that the books are just a huge amount of printed papers. So, full-scale utilization of massive information including key word searching is almost impossible. For effective utilization of invaluable historical earthquake records by wide-ranging researchers and specialists, as well as for improvement of the quality of the collections, construction of a full-text digital database of all existing collections is an urgent task as mentioned in Section 8.

\subsection{Earthquake catalogues}

It is widely considered that the most authoritative catalogue of Japanese historical earthquakes is a series of Usami's books, which is both parametric and descriptive. Usami (1975, 1987, 1996, 2003) has continued publication and revision of the catalogue of all destructive earthquakes in Japan up to date including historical events. His latest version (Usami, 2003) contains 486 historical earthquakes during the period from 416 to 1884 . For 214 events epicentral coordinates (longitude and latitude) and magnitudes are given, for 12 , only epicentral coordinates and 
for 21, only magnitudes, are estimated. For each event, basically, date in both the solar (Gregorian) and the Japanese lunar calendar, time, place name of source region, description and comment are given. For lager events with severe damage rather detailed explanations of macroseismic effects and disaster are provided with maps, tables and graphs. For example, the 1707 Ho'ei earthquake of estimated magnitude 8.6, an interplate event along the Pacific coast of southwest Japan, occupies 16 pages, the 1847 Zenkoji earthquke of estimated magnitude 7.4, an inland shallow event in central Japan, seven pages, and the 1855 Ansei Edo earthquake of magnitude about 7 , an event just beneath the capital Edo (present Tokyo), 10,5 pages. A brief English translation of this catalogue updated to 1995 is available in IASPEI's CD (Usami, 2002c). Figure 9a,b show the epicentral distribution map contained in Usami (2003).
Although Usami's (2003) catalogue is a valuable product of the Japanese historical seismology, personal view and interpretation are considerably presented, and not a few obviously fictitious earthquakes and rather many doubtful events are listed. Another handy catalogue widely consulted by various users is Rika Nenpyo's table introduced in Section 4.2, recent version of which basically follows Usami's catalogue.

\subsection{Intensity database and isoseismal maps}

Seismic intensity distribution maps and isoseismals of Japanese historical earthquakes have been presented for many events by many seismologists as their research products. But the results are not for all historical events, nor prepared by a standardized method, nor compiled

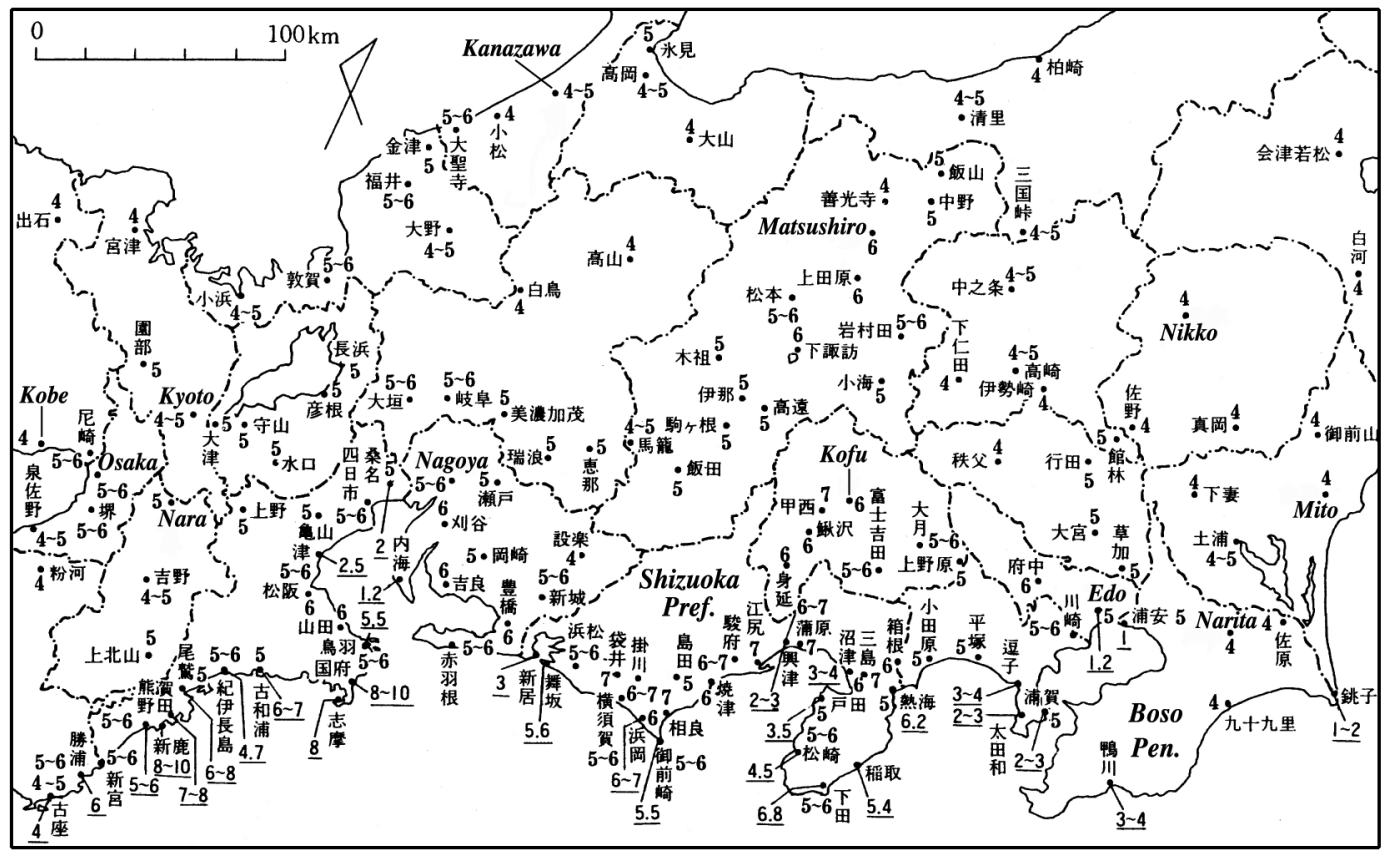

Fig. 10a. Distributions of seismic intensities and tsunamis due to the 1854 Ansei Tokai earthquake illustrated by Ishibashi (1994). Seismic intensities (modified from Usami and Daiwa Exploration and Consulting Co. Ltd., 1994) are on the JMA scale and the numerals underlined represent tsunami heights in meters (after Hatori, 1974, 1977, 1978, 1984). Chinese characters are place names. 


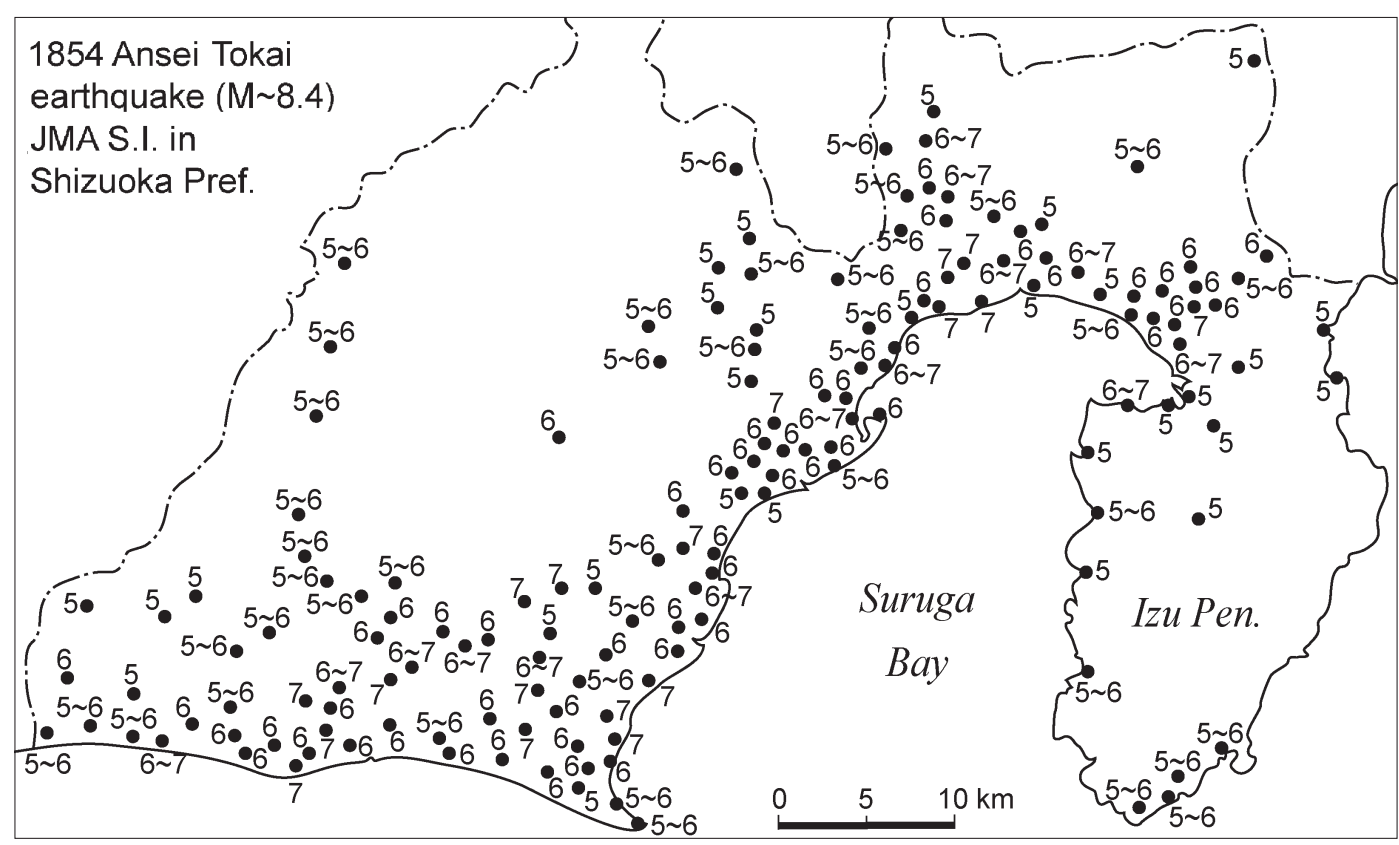

Fig. 10b. Closeup of seismic intensity distribution (on the JMA scale) in Shizuoka Prefecture (lower central part of fig. 10a) due to the 1854 Ansei Tokai earthquake (modified from Usami and Daiwa Exploration and Consulting Co. Ltd., 1994).

systematically. Usami and Daiwa Exploration and Consulting Co. Ltd. (1994) made seismic intensity distributions and isoseismals in a systematic way for almost all destructive historical earthquakes in Japan from 599 till 1884, about 350 in all. The book, however, was not for sale nor distributed widely.

Figure $10 \mathrm{a}, \mathrm{b}$ shows the seismic intensity distributions due to the 1854 Ansei Tokai earthquake (see fig. 11). As can be imagined through from figures, the number of intensity data points, each of which consists of location, time, and seismic intensity, should be extremely large for all historical earthquakes in Japan, although fig. 10a,b is an example of the most dense distribution. It is conjectured that some researchers, groups or companies have prepared kinds of databases of seismic intensity for all historical events. Usami and Daiwa Exploration and Consulting Co. Ltd. (1994), for example, prepared cards of seismic intensities at present-day municipalities for their book accord- ing to the explanation. However, no intensity databases are open to the public use. It is a significant future task to construct a full-scale seismic intensity database of Japanese historical earthquakes.

\section{Some recent results of historical seismology in Japan}

\subsection{Recurrence history of great interplate earthquakes along the Nankai trough}

Great interplate earthquakes associated with the subduction of the Philippine Sea plate have repeatedly occurred along the Suruga-Nankai trough off southwest Japan since A.D. 684 at intervals of 100-200 years. The space-time pattern of their recurrence has been the bestknown in the world; more detailed patterns and related problems have recently been clarified (Ishibashi, 1999b, 2002; fig. 11). 
These great earthquakes occurred as pairs of $M \sim 8$ events, one in the eastern half (Tokai earthquake) and the other in the western half (Nankai earthquake), as was the case for the 1854 Ansei earthquakes, while sometimes occurring as a single giant event like the 1707 Ho'ei earthquake. There are nine series of the Tokai and Nankai earthquakes since 684 down to $1944 / 1946$. The keys to identifying older events are strong ground motion and damage in Kyoto, Nara, and Osaka, those in wider area of southwest Japan, tsunamis along the Pacific coasts of southwest Japan, typical coseismic vertical crustal movements (uplift of the Muroto and Oma'ezaki points and the west coast of Suruga Bay, and subsidence of the Kochi plain, the WSW-ENE running zone across the southern part of Ise Bay and the northern coast of Hamana Lake), temporal inactivity of specific hot springs in Shikoku and the Kii Peninsula, and aftershock activities recorded in Kyoto.

The oldest event, the 684 Hakuho earthquake, is described in Nihon Shoki and is judged to have been definitely a Nankai event based on strong ground motion and severe damage in a broad area including the capital Asuka, tsunami, subsidence of the Kochi plain, and interruption of welling of hot springs in Shikoku and the Kii Peninsula. It may have included a Tokai event simultaneously (possibly Ho'ei type). The 887 Nin'na earthquake was also a definite Nankai event and was probably a Tokai event as well (Ho'ei type; Ishibashi, 2000). The 1096 Eicho earthquake was clearly a Tokai event, and the following 1099 Kowa earthquake was presumably a Nankai event though the evidence is not sufficient. While a Tokai event paired with the 1361 Ko'an (or Shohei) Nankai earthquake had been unknown, Ishibashi (1998b) pointed out that a big shock a few days before the Nankai event, which had been regarded as one of foreshock activity, should have been a Tokai earthquake.

It is uncertain yet whether great earthquakes occurred or not in the $c a .200$ year intervals of 684-887 and 887-1096. It seems probable that great Tokai and Nankai earthquakes took place in the mid-13th century. Although historical records are insufficient in those times, more minute investigation of historical seismology is required to discover missing events (see also Section 7.3).
In 1498, Meio era, presumably both of the Tokai and Nankai earthquakes occurred almost simultaneously as was the case for the 1707 Ho'ei earthquake, but still controversial (e.g., Ishibashi, 1998a; Tsuji and Ueda, 1997). The 1605 Keicho event was obviously a tsunami earthquake (Ishibashi, 1983a; Yamamoto and

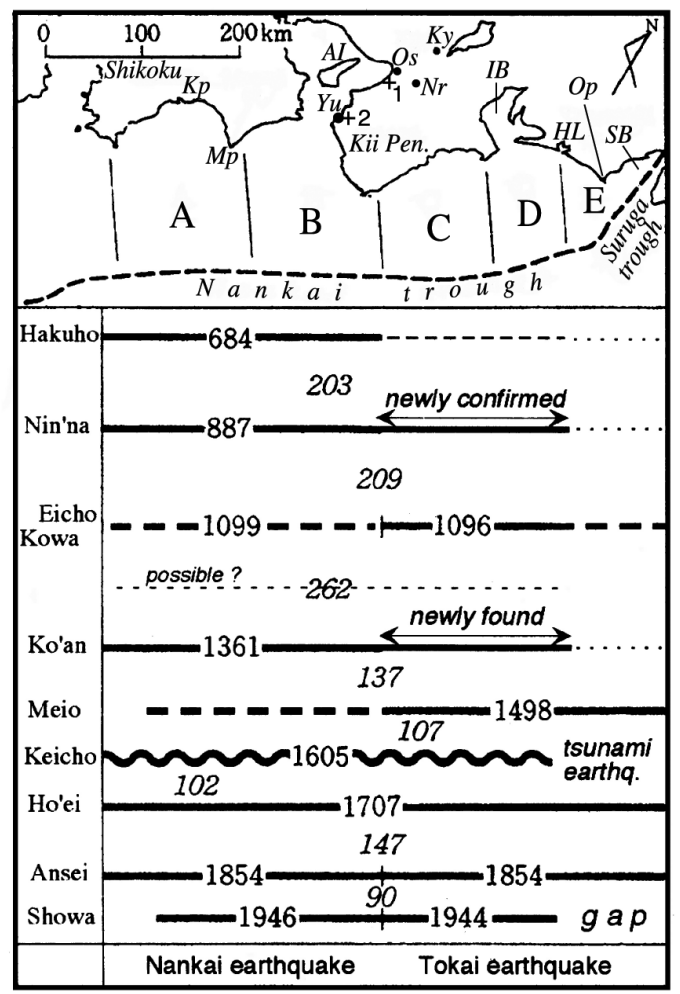

Fig. 11. Space-time distribution of great interplate earthquakes along the Suruga-Nankai trough (modified from fig. 1 in Ishibashi, 2002). Roman and italic numerals indicate earthquake occurrence years and time intervals between two successive series, respectively. Thick solid, thick broken, and thin broken lines represent certain, probable, and possible rupture zones, respectively. Thin dotted lines mean unknown. The left column shows Japanese era names. In the map; 1 Iwatsuta Shrine archaeological site; 2 - Fujinami archaeological site; $A I$ - Awaji Island; $H L$ - Hamana Lake; $I B$ - Ise Bay; $K p$ - Kochi plain; $K y$ - Kyoto; $M p$ - Muroto point; $\mathrm{Nr}$ - Nara; $\mathrm{Op}$ - Oma'ezaki point; $O s$ - Osaka; $S B$ - Suruga Bay; $Y u$ - Yura. A to E are subdivisions of rupture zones commonly used. 
Hagiwara, 1995a); several diaries of court nobles and priests written in Kyoto suggest no ground shaking there. Senko-ji temple in Awaji Island is said to have been destroyed in a secondary literature, which is probably miswriting. The reason it was an anomalous tsunami earthquake may be strongly related to preceding great inland events in 1586 and 1596 (Ishibashi, 1989). The 1707 Ho'ei and 1854 Ansei earthquakes took place in the Edo period causing widespread severe disasters due to strong ground motions and tsunamis, and an enormous number of records has been preserved (see fig. 10a,b).

It should be noted that in the four series of 1096/1099, 1361, 1854 and 1944/1946 the Tokai earthquake preceded the Nankai earthquake by $30 \mathrm{~h}$ to two years. In 1707, and probably in 887 and 1498 as well, the Tokai and the Nankai earthquakes occurred almost simultaneously within the time resolution of historical seismology, $30 \mathrm{~min}$, or a few hours in older times. No reliable smaller earthquakes of $M$ 6 7 are known.

Because the northeastern half of the source region of the 1854 Ansei Tokai earthquake has been unruptured whereas the southwestern half of it was re-ruptured in 1944 and the interseismic crustal movement has been remarkable since the early Meiji era, a great interplate earthquake along the Suruga trough has been considered to be imminent and a nationwide preparedness has been strengthened since 1976 (Ishibashi, 1976, 1981). At present, however, recurrence of the Tonankai (1944-type) and the Nankai earthquakes within a few or several decades has also become a nationwide concern. Thus, the current quiescence zone along the Suruga-Nankai trough clearly seen in fig. 2 is one of the most dangerous place in Japan in terms of long-term earthquake forecasting.

\subsection{Possible fictitious earthquakes}

Since Zotei Dai-nihon Jishin Shiryo (Musha, 1941, 1943a,b), Nihon Jishin Shiryo (Musha, 1951) and Shinshu Nihon Jishin Shiryo (Earthquake Research Institute of the University of Tokyo, 1981-1994) contain considerable amount of low-quality materials such as secondary literature written a long time after the events, and critical reading of such historical documents by seismologists has been very insufficient, it is considered that even Usami's (2002c, 2003) latest catalogue contains at least several fictitious earthquakes (so-called fake earthquakes) and many doubtful events (table II). Careful re-examinations of some of these events have been carried out by Hagiwara et al., $(1982,1989,1995)$ and Ishibashi $(1978,1983 b$, 1994, 1997, 1998c, 1999b). However, systematic discrimination of fictitious earthquakes in catalogues as objectively as possible remains as a future work.

\subsection{The 1233 fictitious (fake) Nankai earthquake}

As an example of identifying a fictitious earthquake, the examination of the 1233 event by Ishibashi (1998c) is introduced below.

Usami (1996) listed the earthquake of 24 March 1233 (in the Gregorian calendar; 17 March in the Julian; 5th day of the 2nd month of the 1st year of Tenpuku in the Japanese lunar calendar) without epicentral coordinates or magnitude (see also table II). Although Usami (1996) added «Damage due to strong wind and heavy rain? Authenticity unclear», he suggested that this earthquake might be responsible for the liquefaction in the first half of the 13th century at Iwatsuta Shrine and Fujinami archaeological sites (see fig. 11), which he thought might have been due to a great Nankai earthquake. Then, the government's Earthquake Investigation Committee put the 1233 earthquake into a tentative data set of the Nankai earthquake for probabilistic evaluation of future occurrence of a great earthquake (Subcommittee for Long-term Evaluation, 1998).

The only basis of Usami's $(1996,2002 c)$ interpretation is Hidaka-gun-shi contained in Musha (1941), which is a kind of chronicle of Hidaka County of Wakayama Prefecture in the Kii Peninsula published in 1923 and cannot be regarded as a primary historical source. Since the brief description in Hidaka-gun-shi on the 1233 event refers to 
Rensenji-ki, Ishibashi (1998c) went back to the latter after checking the original book of Hidaka-gun-shi. Rensenji-ki is a record transmitted from older times in Rensenji temple in Yura Town (see fig. 11) in Hidaka County and was published in type in 1985 by Yura town office.

Concerning the event in question Rensenjiki says «(17 March 1233 in the Julian calendar) there was a large earthquake; enormous disaster in many provinces due to strong wind and rain; uncountable dead and collapsed houses in many areas». We should note, however, Rensenji temple was founded in 1485, far later than 1233, and Rensenji-ki started to be written in 1657 , further afterwards. So, although the record is valuable for the province concerning the Early Modern and Modern ages, descriptions on the Medieval ages are generally unreliable.

Ishibashi (1998c) searched for contemporary original records in 1233 in Kyoto, just 130 km away from Rensenji temple, and found two diaries, Meigetsuki and Minkeiki, written by court nobles. Both are published in type, while the

Table II. Possible ficticious (fake) earthquakes contained in Usami's (2002c) catalogue.

\begin{tabular}{|c|c|c|c|c|c|c|}
\hline No. & $\begin{array}{c}\text { Date } \\
(\mathrm{D} / \mathrm{M} / \mathrm{Y})\end{array}$ & $\begin{array}{l}\text { Epicenter } \\
\text { Lat.-Long. }\end{array}$ & $M$ & Deaths & Area/outline of the damage & Ref. \\
\hline & $2 / 8 / 887$ & Echigo & & $\begin{array}{l}\text { Thousands } \\
\text { drowned }\end{array}$ & Tidal wave. & 1 \\
\hline & $24 / 3 / 1233$ & Many countries & & Many & $\begin{array}{l}\text { Many houses collapsed by large earthquake, } \\
\text { strong storm and heavy rain. }\end{array}$ & 2 \\
\hline 046 & $22 / 5 / 1241$ & Kamakura & 7.0 & & $\begin{array}{l}\text { Yuigahama: worship hall behind big torii } \\
\text { washed away, } 10 \text { ships on coast destroyed. }\end{array}$ & \\
\hline \multirow[t]{3}{*}{054} & $22 / 11 / 1360$ & $33.4-136.2$ & 7.75 & Many & $\begin{array}{l}\text { Tsunami hits between Kumano-Owase and } \\
\text { Osaka-Hyogo shore, large damage. }\end{array}$ & 3 \\
\hline & $7 / 11 / 1433$ & $37.7-139.8$ & 6.7 & & $\begin{array}{l}\text { Hachimangu shrine: structures collapsed } \\
\text { (doubtful). }\end{array}$ & 4 \\
\hline & $7 / 12 / 1646$ & Edo & & & $\begin{array}{l}\text { Houses destroyed, fissures; Edo castle: } \\
\text { stone walls slightly destroyed. }\end{array}$ & 5 \\
\hline 106 & $13 / 6 / 1648$ & $35.2-139.2$ & 7.0 & 1 & $\begin{array}{l}\text { Edo: tiles fall down, half of earthen walls } \\
\text { destroyed; Odawara: many houses col- } \\
\text { lapsed; Odawara castle: } 18 \text { m of stone walls } \\
\text { collapsed, tiles of towers and gates partially } \\
\text { fell down, walls slightly destroyed; Hakone: } \\
1 \text { dead by fallen rocks. }\end{array}$ & 6 \\
\hline \multirow[t]{2}{*}{158} & $20 / 12 / 1711$ & $34.3-134.0$ & 6.7 & 1000 odd & $\begin{array}{l}1073 \text { houses collapsed, banks destroyed, } \\
\text { fissures, a root of a pine tree extracted, } \\
\text { tsunami hits } 10 \text { times; (doubtful) damages } \\
\text { in Takamatsu territory only. }\end{array}$ & 7 \\
\hline & $29 / 8 / 1784$ & Edo & 6.1 & & Houses shock, tiles fell down. & 8 \\
\hline
\end{tabular}


original scripts are preserved as national treasures (fig. 5a). Though both of them contain many descriptions of earthquakes, they described nothing suggesting earthquakes, strong wind and rain, or disasters on and around the 5th day, 2nd month, the 1st year of Tenpuku. The two diaries also have everyday weather records, which are consistent with each other, suggesting no stormy day around the date in question.

Although «the absence of evidence is not the evidence of absence», in this case we can deny the description of Rensenji-ki by much more reliable contemporary records, especially by everyday weather records. Thus, occurrence of a Nankai earthquake or any large earthquake around Kyoto and the Kii Peninsula on 17 March 1233 in the Julian calendar is denied.

As for evidence of past liquefactions obtained by archaeoseismology, we should note generally that they are just evidence of strong ground motion at the sites and cannot tell where causative earthquakes took place, or exactly when.

\section{Future problems}

In a review paper on Japanese historical seismology in the framework of earthquake prediction research (Ishibashi, 1987), I pointed out two problems to be solved quickly for this field to contribute more to earthquake sciences. One was the absence of research sections and full-time scientists having official responsibility for historical seismology. The other was the difficulty of analyzing huge collections of historical documents in book-form only. I proposed 1) establishment of a new research office(s) specializing in historical seismology, which would also be a center(s) of collaboration between seismologists and historians and for collection and maintenance of historical records, and 2) construction of a database system of the whole historical earthquake documents in Japan for a wide variety of researchers and specialists using a personal computer and CD-ROM.

At present, however, these two proposals have not yet been implemented. As for the first point, the present situation of the historical seismology in Japan seems to be worse. The most serious problem is an extreme scarcity of researchers in this field, especially among the younger generation. For the study of historical seismology, interest, knowledge and sense in both seismology and historical sciences are required. It is very difficult, however, to cultivate such multi-disciplinary researchers in the present system of education and research of earthquake science. In this respect historical seismology exhibits a striking contrast to paleoseismology, in which a certain number of younger specialists has been continuously educated.

Concerning the second point, discussions and a small-scale project of constructing a database of historical earthquake documents were started following my proposal (e.g., Ishibashi et al., 1989; Iwasaki et al., 1990; Iwasaki, 1999). However, because of the limitation of budget, manpower and computer ability, the project was not successful.

Koyama (1999) pointed out basic problems in current historical seismology in Japan as follows:

1) Insufficiency of critical examination of quality of historical documents and selection;

2) Uncertainty in estimated epicenters and magnitudes and tectonic interpretation in Usami's (1996) catalogue;

3) Absence of database of historical earthquake records;

4) Adoption of the Gregorian calendar throughout historical times;

5) Insufficient awareness of the spatial and temporal heterogeneity of historical earthquake records;

6) Lack of examination into recording characteristics of each historical document;

7) Insufficiency of present and future researchers;

8) Misunderstanding about historical seismology by researchers of neighboring fields. Most of these points have been discussed in this paper.

Despite these fundamental problems, basic products of historical seismology, such as collected historical records, estimated seismic intensities and earthquake history in each region, have become increasingly important for advanced earthquake studies and preparedness. 
Some recent remarkable examples include the evaluation of spatial distribution of asperities (short-period wave radiation zones) on the fault planes of the 1707, 1854 and 1944-1946 great Tokai-Nankai earthquakes through inversion of seismic intensity data (Kanda et al., 2003) and inference of the time and size of the 1700 giant Cascadia, the Pacific coast of North America, earthquake from Japanese tsunami records (Satake et al., 1996, 2003; Tsuji et al., 1998). Furthermore, seismic intensity maps of historical earthquakes are keys for calibrating calculated results of strong ground motion due to future large events, and earthquake history in various regions are essential for probabilistic evaluation of future destructive earthquakes and assessment of potential of active faults, all of which are recently intensified subjects of earthquake preparedness in Japan. Thus, offering much more reliable and objective data and results on past earthquakes is a serious task of historical seismology.

Ishibashi et al. (2003) has started a research project of constructing a full-text digital database of all historical earthquake documents in the Ancient and Medieval ages under the Grantsin-Aid for Scientific Research by MEXT (Ministry of Education, Culture, Sports, Science and Technology). Although the project term is limited to four years, we plan to critically examine all the historical documents in the existing collections, select them, carefully emend every text and compose a re-edited collection of all historical documents in digital form. We also aim at interdisciplinary collaboration among seismologists, volcanologists, historians and information scientists. Furthermore we intend to compose a seismic intensity database compatible with the so-called Intensity Data Points (IDP; e.g., Stucchi, 1994) and containing some additional elements such as the characteristics of ground motion. So far, Japanese seismologists have unconsciously considered that study of Japanese historical earthquakes, methodology and procedure themselves except obtained results, are only of interest within Japan because of the peculiarity of Japanese language, culture and history. However, historical seismology in every part of the world is a global interest like other fields of earthquake sciences.
Ishibashi et al. (2003) are restricting the target within the Ancient and Medieval ages because historical sources in these times have somewhat different characteristics from those in the Early Modern ages and historical records in the Early Modern (mostly the Edo period) are too huge an amount to be treated by a small research group. Works on the Edo period should be done as a national project, like the large-scale instrumental observation of current earthquakes. Then, the result will be a great contribution to the international earthquake study.

\section{Acknowledgements}

I wish to express my gratitude to Enzo Boschi, Virginia Garcia Acosta, Roger M.W. Musson and Massimiliano Stucchi for inviting me to the Workshop «Investigating the records of past earthquakes» held as the 21st Course of EMFCSC International School of Geophysics at Erice, Sicily, in July, 2002. Special thanks are due to Massimiliano Stucchi, Paola Albini and their colleagues at the Milan Section of Istituto Nazionale di Geofisica e Vulcanologia (INGV), Italy, for their kind help in the Workshop and during the course of preparation of this paper. I am also grateful to «Ettore Majorana» Foundation and Centre for Scientific Culture (EMFCSC), Italy, for its support for my stay in Sicily and to Kansai Research Foundation for Technology Promotion, Japan, for its support of transportation expenses. I am deeply indebted to Brian F. Atwater and Kenji Satake for critically reading the manuscript and making many invaluable comments and suggestions. I also thank an anonymous reviewer for helpful comments and encouragement, and Shigeto Yoritomi for his help in preparing some of the figures. Figure 2 was drawn by GMT (Generic Mapping Tools, Wessel and Smith, 1995).

\section{REFERENCES}

EARTHQUAKE RESEARCH InSTITUTE OF THE UNIVERSITY OF TOKYO (Editor) (1981-1994): Historical Documents on Earthquakes in Japan, vols. 1-5 (suppl. 2), New Collection (in Japanese).

Earthquake Research COMmittee, Headquarters for EARThQuaKe Research Promotion, Prime Minister’s 
OfFICE, Government of JAPAN (1998): Seismic Activity in Japan Regional Perspectives on the Characteris tics of Destructive Earthquakes (Excerpt), pp. 222.

Hagiwara, T. (1989): Formation and change of 'Chronological Table of Damaging Earthquakes in and around Japan' in «Rika Nenpyo», in Old Earthquakes - Real and Virtual Images, edited by T. HAGIWARA (University of Tokyo Press), 2nd ser., 3-25 (in Japanese).

Hagiwara, T., K. Huzita, T. Yamamoto, T. Matsuda and A. DAICHO (1982): Old Earthquakes Investigate through Historical Documents and Active Faults (University of Tokyo Press), pp. 312 (in Japanese).

Hagiwara, T., K. Huzita, T. Yamamoto, T. Matsuda and A. DAICHO (1989): Old Earthquakes - Real and Virtual Images (University of Tokyo Press), 2nd ser., pp. 434 (in Japanese)

Hagiwara, T., T. Yamamoto, Y. Ota, A. Daicho and T. Matsuda (1995): Pursuit of Old Earthquakes (Kojishin Tankyu) Approach to Offshore Earthquakes (University of Tokyo Press), pp. 306 (in Japanese)

HATORI, T. (1974): Sources of large tsunamis in southwes Japan, J. Seismol. Soc. Jpn., Ser. 2, 27, 10-24 (in Japanese with English abstract)

HATORI, T. (1977): Field investigation of the Tokai tsunamis in 1707 and 1854 along the Shizuoka coast, Bull. Earthquake Res. Inst., Univ. Tokyo, 52, 407-439 (in Japanese with English abstract).

HATORI, T. (1978): Field investigation of the Tokai tsunamis in 1707 and 1854 along the Mie coast, east Kii Peninsula, Bull. Earthquake Res. Inst., Univ. Tokyo, 53, 1191-1225 (in Japanese with English abstract).

HATORI, T. (1984): Behavior of the Tokai tsunamis of 1707 and 1854 in the Kanto and east Izu districts, Bull. Earthquake Res. Inst., Univ. Tokyo, 59, 501-518 (in Japanese with English abstract).

HATTORI, I. (1878): Destructive earthquakes in Japan, Trans. Asiatic Soc. Jpn., 6, 249-275.

HAYAKAWA, Y. and M. KoYAMA (1997): Which calendar shall we adopt to describe dates of volcanic eruptions older than 1582 A.D., the Gregorian or Julian?, J. Geogr., 106, 102-104 (in Japanese).

HistoriogRAPHICAL INSTITUTE OF THE UNIVERSITY OF TOKYO (Editor) (1901-): Collection of Historical Documents in Great Japan - Chronological Source Books of Japanese History, 370 volumes as of March 2004 (University of Tokyo Press, including reissues since 1968), (in Japanese).

IMAMURA, A. (1925): Chronological table of large earthquakes in this country, in Chronological Scientific Tables, edited by TOKYO ASTRONOMICAL OBSERVATORY (Maruzen Co., Ltd.), no. 1, pp. 282-293 (in Japanese).

IMAMURA, A. (1933): Riddle of the great off-Nankaido earthquake, J. Seismol. Soc. Jpn., Ser. 1, 5, 607-626 (in Japanese).

Imamura, A. (1937): Theoretical and Applied Seismology (Maruzen Co., Tokyo), pp. 358.

IMAMURA, A. (1943): On the tilt of the southeastern Enshu block, J. Seismol. Soc. Jpn., Ser. 1, 15, 217-224 (in Japanese).

ISHIBASHI, K. (1976): Re-examination of a great earthquake expected in the Tokai district: possibility of the «Suruga Bay earthquake», Abstracts, Seismol. Soc. Jpn., 1976 (2), 30-34 (in Japanese).
IsHiBASHI, K. (1978): Notes on some destructive earthquakes in the Kanto district that preceded the 1703 great Genroku-Kanto earthquake, 1. The severe earthquake of 1648 June 12, J. Seismol. Soc. Jpn., Ser. 2, 31, 342-345 (in Japanese).

ISHIBASHI, K. (1981): Specification of a soon-to-occur seismic faulting in the Tokai district, central Japan, based upon seismotectonics, in Earthquake Prediction - An International Review, edited by D.W. SIMPSON and P.G. RICHARDS, (Am. Geophys. Un., Washington DC), Maurice Ewing Ser. 4, pp. 297-332.

IsHIBASHI, K. (1983a): Tectonic significance of the 1605 (Keicho 9th) Tokai-Nankai tsunami earthquake, Programme and Abstracts, Seismol. Soc. Jpn., 1983 (1), p. 96 (in Japanese).

ISHIBASHI, K. (1983b): Unreality of the 1433 Aizu earthquake (M 6.7) in Northeast Japan, J. Seismol. Soc. Jpn., Ser. 2, 36, 169-176 (in Japanese with English abstract).

IsHIBASHI, K. (1985): Possibility of a large earthquake near Odawara, Central Japan, preceding the Tokai earthquake, Earthquake Predict. Res., 3, 319-344.

IsHIBASHI, K. (1987): A review of the current historical seismology in Japan from the viewpoint of earthquake prediction research, in Proceedings of Earthquake Prediction Research Symposium (National Committee for Seismology in Science Council of Japan, and Seismological Society of Japan), 129-142 (in Japanese with English abstract)

IsHIBASHI, K. (1989): Possible activity of the Median Tectonic Line during the 1596 Keicho Kinki earthquake and its effect on the 1605 tsunami earthquake along the Nankai trough, Programme and Abstracts, Seismol. Soc. Jpn., 1989 (1), p. 62 (in Japanese).

IsHIBASHI, K. (1994): An Era of Underground Convulsions (Iwanami Shoten, Tokyo), pp. 234 (in Japanese).

ISHIBASHI, K. (1995a): Re-examination of destructive earthquakes originated beneath the Tokyo metropolitan area, Japan, during the Edo era (1603-1867), 1. The 1646 December 7 earthquake was not destructive in Edo, $J$. Seismol. Soc. Jpn., Ser. 2, 48, 113-115 (in Japanese).

IsHIBASHI, K. (1995b): Problems in the study of old earthquakes, in Exploring Old Earthquakes, edited by Y. OTA and K. SHIMAZAKI (Kokon Shoin, Tokyo), 193-207 (in Japanese).

IsHIBASHI, K. (1997): Re-examination of destructive earthquakes originated beneath the Tokyo metropolitan area, Japan, during the Edo era (1603-1867), 2. The 1670 Kanbun Sagami earthquake is imaginary, J. Seismol. Soc. Jpn., Ser. 2, 50, 345-347 (in Japanese).

ISHIBASHI, K. (1998a): Was the earthquake of July 9, 1498 in southwest Japan really the great Nankai earthquake?, Abstracts of the 1998 Japan Earth and Planetary Science Joint Meeting, p. 313 (in Japanese).

IsHIBASHI, K. (1998b): Inferred Tokai earthquake paired with the 1361 Shohei Nankai earthquake, in Programme and Abstracts, Seismol. Soc. Jpn., 1998 Fall Meeting, p. 125 (in Japanese).

IsHIBASHI, K. (1998c): No great Nankai earthquake occurred on March 17, 1233, J. Seismol. Soc. Jpn., Ser. 2, 51, 335-338 (in Japanese).

IsHIBASHI, K. (1999a): The 1819 disastrous Bunsei Ohmi earthquake that occurred within the Philippine Sea slab beneath central Japan, in Abstracts of the 1999 Japan 
Earth and Planetary Science Joint Meeting, As-005 (CDROM), (on line: http://www-jm.eps.s.u-tokyo.ac.jp/ 1999cd-rom/html/author/fifty/fif01_04.htm), (in Japanese with English abstract).

IsHIBASHI, K. (1999b): Great Tokai and Nankai, Japan, earthquakes as revealed by historical seismology, 1 . Review of the events until the mid-14th century, J. Geogr., 108, 399-423 (in Japanese with English abstract). IsHIBASHI, K. (2000): Certainty that the 887 Nin'na earthquake included great Tokai and Nankai events, in $A b$ stracts of the 2000 Japan Earth and Planetary Science Joint Meeting, SI-017 (CD-ROM) (on line: http://www-jm.eps.s.u-tokyo.ac.jp/2000cd-rom/ html/author/fifty/fif02_3.htm), (in Japanese with English abstract).

IsHIBASHI, K. (2002): Great Tokai and Nankai, Japan, earthquakes as boundary conditions for the Philippine Sea slab: Review from historical seismology, in Proc. Meeting 13K-7 (DPRI, Kyoto Univ.), 1-9 (in Japanese with English abstract).

Ishibashi, K., T. YoshiI, Y. Tsuji, K. Kasahara, M. KomINAMI and S. IWASAKI (1989): On construction of a database of the existing collections of historical earthquake documents, Programme and Abstracts, Seismol. Soc. Jpn., 1989 (1), p. 225 (in Japanese).

Ishibashi, K., M. Koyama, K. Satake, Y. Tsuji, Y. Hayakawa, M. Ebara, S. Sasamoto, M. Takahashi, S. TARashima, A. Fujita, T. Yata, H. Yasunaga and S. HARA (2003): Recension and digitization of all historical earthquake documents in Japan during ancient and medieval periods, in Programme and Abstracts, Seismol. Soc. Japan, 2003 Fall Meeting, C023 (in Japanese).

IWASAKI, S. (1999): Current status and future remarks about an electronic data-base system of collected historical documents on earthquakes and related phenomena, $J$. Geogr., 108, 465-471 (in Japanese with English abstract).

Iwasaki, S., T. YoshiI, Y. Tsuji, K. IshiBAshi, K. KASAHARA and M. KOMINAMI (1990): Construction of the database of old documents on historical earthquakes, Programme and Abstracts, Seismol. Soc. Japan, 1990 (1), p. 182 (in Japanese).

KANDA, K., M. TAKemura and T. Usami (2003): Fault area radiating short-period seismic waves during great earthquakes at the Nankai trough seismogenic zone, in Abstracts of the 2003 Japan Earth and Planetary Science Joint Meeting, S069-P004 (CD-ROM), (on line: http://www-jm.eps.s.u-tokyo.ac.jp/2003cdrom/pdf/s069/s069-p004_e.pdf), (in Japanese with English abstract).

Katsumata, M. and K. Tokunaga (1971): Relation between isoseismal area of intensity IV and earthquake magnitude, and earthquake intensity of J.M.A. with corresponding maximum acceleration, Quart. J. Seismol., 36, 89-96 (in Japanese).

KAWASUMI, H. (1943): Seismic intensity and intensity scale, J. Seismol. Soc. Jpn., Ser. 1, 15, 6-12 (in Japanese).

KAWASUMI, H. (1951): Measures of earthquake danger and expectancy of maximum intensity throughout Japan as inferred from seismic activity in historical times, Bull. Earthq. Res. Inst., Univ. Tokyo, 29, 469-482.

KitAhara, I. (1983): The Large Ansei Earthquake and the Masses (San'ichi Shobo, Tokyo), pp. 264 (in Japanese).

Koyama, M. (1999): A review of historical seismology in Japan: Analyses and proposals for next stage of study of historical documents, J. Geogr., 108, 346-369 (in Japanese with English abstract).

KoYAma, M. and Y. HAYAKawa (1998): How shall we describe dates of historic earthquakes and volcanic eruptions?, in Abstracts of the 1998 Japan Earth and Planetary Science Joint Meeting, p. 328 (in Japanese).

KuroitA, K. (Editor) (1932, 1933a): Azuma Kagami, Parts 1 and 2, in Summa of Japanese Historical Sources, 32 and 33 (Yoshikawa Kobunkan, Tokyo), revised and enlarged edition, pp. 800 and pp. 874 (in Japanese).

KuroiTA, K. (Editor) (1933b, 1934a): Ruiju Kokushi (Classified National History compiled by Sugawara no Michizane, ca. 900), Parts 1 and 2, in Summa of Japanese Historical Sources, 5 and 6 (Yoshikawa Kobunkan, Tokyo), revised and enlarged edition, pp. 546 and pp. $383+158$ (in Japanese).

KuroitA, K. (Editor) (1934b): Nihon Koki, Shoku Nihon Koki, Nihon Montoku-Ten'no Jitsuroku (3rd, 4th and 5th books of «Rikkokushi»), in Summa of Japanese Historical Sources, 3 (Yoshikawa Kobunkan, Tokyo), revised and enlarged edition, pp. 138, 246 and 126 (in Japanese).

KuROITA, K. (Editor) (1934c): Nihon Sandai Jitsuroku (6th book of «Rikkokushi»), in Summa of Japanese Historical Sources, 4 (Yoshikawa Kobunkan, Tokyo), revised and enlarged edition, pp. 643 (in Japanese).

KuROITA, K. (Editor) (1935): Shoku Nihongi (2nd book of «Rikkokushi»), Shintei Zoho Kokushi Taikei (Summa of Japanese Historical Sources, Revised and Enlarged Edition), 2 (Yoshikawa Kobunkan, Tokyo), pp. 561 (in Japanese)

KuroitA, K. (Editor) (1951, 1952): Nihon Shoki (1st book of «Rikkokushi»), Parts 1 and 2, in Summa of Japanese Historical Sources, 1A and 1B (Yoshikawa Kobunkan, Tokyo), revised and enlarged edition, pp. 419 and pp. 437 (in Japanese).

LEE, W.H.K., H. Meyers and K. SHIMAZAKI (Editors) (1988): Historical Seismograms and Earthquakes of the World (Academic Press, San Diego, U.S.A.), pp. 513.

MatsudA, T. (1999): Collating records in nature and in history: contribution to earthquake prediction, J. Geogr. 108, 370-377 (in Japanese with English abstract).

Matsu'URA, R.S., I. KARAKAMA and M. NAKAMURA (1999): Reexamination of hypocenters and magnitudes for historical earthquakes, Part 1, in Programme and Abstracts, Seismol. Soc. Japan, 1999 Fall Meeting, C35 (in Japanese).

Matsu'URA, R.S., I. KARAKAMA and M. NAKAmURA (2000): Reexamination of hypocenters and magnitudes for historical earthquakes, Part 2, in Programme and $A b$ stracts, Seismol. Soc. Japan, 2000 Fall Meeting, C23 (in Japanese).

Matsu'URA, R.S., M. NAKAmURA and I. KARAKAma (2001): Reexamination of hypocenters and magnitudes for historical earthquakes, Part 3, in Programme and Abstracts, Seismol. Soc. Japan, 2001 Fall Meeting, B74 (in Japanese).

Matsu'ura, R. S., M. Nakamura, I. Karakama and I. KAYANO (2002): Reexamination of hypocenters and magnitudes for historical earthquakes, Part 4, in Pro- 
gramme and Abstracts, Seismol. Soc. Japan, 2002 Fall Meeting, C66 (in Japanese)

Matsu'URA, R.S., M. NaKamura, I. Karakama and I. KAYANO (2003): Reexamination of hypocenters and magnitudes for historical earthquakes, Part 5, in Programme and Abstracts, Seismol. Soc. Japan, 2003 Fall Meeting, $\mathrm{C} 024$ (in Japanese).

MiKI, H. (1979): The Large Kyoto Earthquake (Shibunkaku Shuppan, Kyoto), pp. 334 (in Japanese)

MiLNE, J. (1881): Notes on the great earthquakes of Japan, Trans. Seismol. Soc. Jpn., 3, 65-102.

MoRISUE, Y, T. ICHIKO and S. TSUTSUMI (Editors) (1963-76) All-inclusive Catalogue of Japanese Writings, vols. 1-8 + suppl. (Iwanami Shoten, Tokyo), revised edition 1997 2003 , pp. 725 , pp. 724 , pp. 882 , pp. 802 , pp. 902 , pp 868 , pp. 950 , pp. $859+$ pp. 1010 (in Japanese)

Muramatu, I. (1969): Relation between the distribution of seismic intensity and the earthquake magnitude, Sci. Rep. Fac. Educ., Gifu Univ. (Natural Science), 4, 168176 (in Japanese with English abstract)

MusHA, K. (Editor) (1941, 1943a,b): Historical Documents on Earthquakes in Great Japan, vols. 1-3 (Earthquake Prevention Council, Ministry of Education), enlarged and revised edition, pp. 945, pp. 754, pp. 945 (in Japanese).

Musha, K. (Editor) (1951): Historical Documents on Earthquakes in Japan (The Mainichi Newspapers Co.), pp. 757 (in Japanese)

NAUMANN, E. (1878): Über Erdbeben und Vulcanausbrüeche in Japan, Mit. der Deutsch Gesellschaft fur Natur- und Volker-kunde Ostasiens, 2, 163-216 (in German).

Ogashima, H. (Editor) (1894): Natural Disasters in Japan (Nihon Kogyokai, Tokyo), pp. 874 (in Japanese).

OMORI, F. (1913): General descriptions of Japanese large earthquakes, Rep. Imp. Earthquake Inv. Comm., No. 68B, 1-180 (in Japanese).

OMORI, F. (1919): Descriptive table of Japanese large earthquakes, Rep. Imp. Earthquake Inv. Comm., No. 88B, 1 71 (in Japanese).

OTA, Y. and K. ShimaZaKi (Editors) (1995): Exploring Old Earthquakes (Kokon Shoin, Tokyo), pp. 215 (in Japanese).

ReizeIKe SHiguretei BunKo (Editor) (2003): Meigetsuki, No. 5, Reizeike Shiguretei Ser. 60 (Asahi Shimbun, Tokyo), pp. 628+23 (in Japanese).

SANGAWA, A. (1992): Earthquake Archaeology (Chuokoron-sha, Tokyo), pp. 251 (in Japanese).

Satake, K., K. Shimazaki, Y. TsujI and K. Ueda (1996) Time and size of a giant earthquake in Cascadia inferred from Japanese tsunami records of January 1700, Nature, 379, 246-249.

SAtAKe, K., K. WANG and B.F. AtwATER (2003): Fault slip and seismic moment of the 1700 Cascadia earthquake inferred from Japanese tsunami descriptions, J. Geophys. Res., 108 (B11), 2535, doi:10.1029/2003JB002521.

SeISMological Division of THE JMA (1971): The records of seismic intensity observed in Japan, Technical Report of the Japan Meteorological Agency, No. 76, pp. 222 (in Japanese with English abstract).

STUCCHI, M. (1994): Recommendations for the compilation of a European parametric earthquake catalogue, with special reference to historical records, in Historical Investigation of European Earthquakes, edited by P. AL-
BINI and A. Moroni (CNR, Milano), vol. 2, 181-190. SubCOMMITTEE FOR LONG-TERM EVALUATION, EARTHQUAKE Research COMmitTeE, Headquarters FOR EARTHQUaKe Research Promotion (1998): On Evaluation Methods and Application Examples of Probabilities of Long-term Earthquake Occurrence (Tentative Draft), pp. 73 (in Japanese).

TAKEMURA, M. (1999): Two big aftershocks immediately after the 1923 Kanto earthquake: Strong ground motions and locations of the epicenters, J. Geogr., 108, 440-457 (in Japanese with English abstract).

TAKEMURA, M. (2001): The Taisho Kanto earthquake as a historical earthquake - Elucidation of the temporal and spatial characteristics of strong ground motions, Chikyu Monthly, 23, 138-146 (in Japanese).

TAYAMA, M. (Editor) (1904a,b): Historical Documents on Earthquakes in Great Japan, I and II, Rep. Imp. Earthq. Inv. Comm., No. 46A, pp. 606 and No. 46B, pp. 595 (in Japanese).

TAYAMA, M. (1904c): Catalogue of earthquakes, Appendix to Historical Documents on Earthquakes in Great Japan, Rep. Imp. Earthq. Inv. Comm., No. 46B, pp. 45 (in Japanese).

TsuJI, Y. (Editor) (1979a,b): Historical documents on earthquakes and tsunamis in the Tokai district, IA and IB, Rev. Res. Disast. Prev., No. 35, pp. 436 and No. 36, pp. 857 (in Japanese).

Tsuji, Y. and K. UEDA (1997): Proof of the existence of the 1498 Meio Nankai earthquake and the date of its occurrence, in Abstracts of the 1997 Japan Earth and Planetary Science Joint Meeting, p. 169 (in Japanese).

TsuJI, Y., K. UEDA and K. SATAKE (1998): Japanese tsunami records from January 1700 earthquake in the Cascadia subduction zone, J. Seismol. Soc. Jpn., Ser. 2, 51, 1-17 (in Japanese with English abstract).

UsAMI, T. (1975): Materials for Comprehensive List of Destructive Earthquakes in Japan (University of Tokyo Press), pp. 327 (in Japanese).

UsAmI, T. (1979): Study of historical earthquakes in Japan, Bull. Earthquake Res. Inst., Univ. Tokyo, 54, 399-439.

UsAmI, T. (1982): Great earthquakes of the past, in Earthquake Prediction Techniques, edited by T. AsADA (University of Tokyo Press), 11-29.

Usami, T. (1986): Commencement of Investigation of Historical Earthquakes, pp. 185 (in Japanese).

UsAmI, T. (1987): Materials for Comprehensive List of Destructive Earthquakes in Japan (University of Tokyo Press), new edition, pp. 434 (in Japanese).

UsAmI, T. (1988): Study of historical earthquakes in Japan, in Historical Seismograms and Earthquakes of the World, edited by W.H.K. LEE, H. MEYERS and K. SHIMAZAKI (Academic Press, San Diego, U.S.A.), 276-288.

UsAMI, T. (1996): Materials for Comprehensive List of Destructive Earthquakes in Japan 416-1995 (University of Tokyo Press), revised and enlarged edition (CDROM version published in 1997), pp. 493 (in Japanese).

Usami, T. (Editor) (1998, 1999): Historical Documents on Earthquakes in Japan: Gleanings, Gleanings Supplement (Japan Electric Association), pp. 512, pp. 1045 (in Japanese).

UsAmi, T. (Editor) (2002a): Historical Documents on Earthquakes in Japan: Gleanings 2, pp. 583 (in Japanese). 
UsAmI, T. (2002b): Historical earthquakes in Japan, in International Handbook of Earthquake and Engineering Seismology, Part A, edited by W.H.K. LEE, H. KANAMORI, P.C. JENNINGS and C. KISSLINGER (IASPEI, Academic Press), 799-802 (full manuscript is given in UsamiFull.pdf on the attached Handbook CD \#1, directory/48.4Usami).

UsAmI, T. (2002c): Table of historical damaging earthquakes in Japan (English translations of an originally Japanese-language publication, updated to 1995), in Handbook CD \#1 (directory/48.4Usami, compiled by M.F. DigGLES and W.H.K. LEE), enclosed in International Handbook of Earthquake and Engineering Seismology, Part A, edited by W.H.K. LeE, H. KANAMORI, P.C. Jennings and C. Kisslinger (IASPEI, Academic Press).

Usami, T. (2003): Materials for Comprehensive List of Destructive Earthquakes in Japan [416]-2001 (University of Tokyo Press), pp. 605 (in Japanese).

UsAmI, T. and HIS COLLABORATORS (1986): Intensity distribution of four large earthquakes off the Tokai district, Rep. Coord. Comm. Earthq. Predict., 35, 343-352 (in Japanese).

Usami, T. and Daiwa Exploration \& Consulting Co. LTD. (Editors) (1994): Seismic Intensity Distributions and Isoseismal Maps of the Japanese Historical Earthquakes (Japan Electric Association), pp. 647 (in Japanese).

Utsu, T. (1979): Seismicity of Japan from 1885 through 1925 - A new catalog of earthquakes of $M>6$ felt in Japan and small earthquakes which caused damage in Japan, Bull. Earthquake Res. Inst., Univ. Tokyo, 54, 253-308 (in Japanese with English abstract).

UTSU, T. (1982): Seismicity of Japan from 1885 through 1925, Bull. Earthq. Res. Inst., Univ. Tokyo, 57 (correction and supplement), 111-117 (in Japanese with English abstract).
UTSU, T. (1988): A catalog of large earthquakes $(M \geq 6)$ and damaging earthquakes in Japan for the years 1885-1925, in Historical Seismograms and Earthquakes of the World, edited by W.H.K. LeE, H. MeYerS and K. SHIMAZAKI (Academic Press, San Diego, U.S.A.), 150-161.

UTsu, T. (1989): Distribution of Seismic Intensities for Large Earthquakes $(M \geq 6.0)$ and Damaging Earthquakes in Japan (1901 1926), Earthq. Res. Inst., Univ. Tokyo, pp. 278 (in Japanese).

UTSU, T. (1990): A Table of Damaging Earthquakes in the World (from Ancient Times through 1989), pp. 243 (in Japanese).

UTsu, T. (2002): Relationships between magnitude scales, in International Handbook of Earthquake and Engineering Seismology, Part A, edited by W.H.K. LEE, H. KANAMORI, P.C. JENNINGS and C. KISSLINGER (IASPEI, Academic Press), 733-746 (full manuscript is given in Utsu3FullManuscript.pdf on the attached Handbook CD \#1, directory/44Utsu3).

Wessel, P. and W.H.F. SMITH (1995): New version of the generic mapping tools released, EOS Trans. Am. Geophys. Un., 76, pp. 329.

YAMAMOTO, T. and T. Hagiwara (1989): Four doubtful Seaof-Kumano earthquakes, in Old Earthquakes - Real and Virtual Images, 2nd Ser, edited by T. HAGIWARA (University of Tokyo Press), 241-266 (in Japanese).

YAMAMOTO, T. and T. Hagiwara (1995a): On the earthquake of the 16th day of the 12th month in the 9 th year of Keicho (1605) - Tsunami earthquake off TokaiNankai?, in Pursuit of Old Earthquakes - Approach to Offshore Earthquakes, edited by T. HAGIWARA (University of Tokyo Press), 160-251 (in Japanese).

YAmamoto, T. and T. Hagiwara (1995b): The Sanuki-Takamatsu earthquake of 11th day of the 11th month in the 1st year of Shotoku (1711), in Pursuit of Old Earthquakes Approach to Offshore Earthquakes, edited by T. HAGIWARA (University of Tokyo Press), 252-263 (in Japanese). 